\title{
Bronchial lesions of mouse model of asthma are preceded by immune complex vasculitis and induced bronchial associated lymphoid tissue (iBALT)
}

\author{
Ian C Guest ${ }^{1}$ and Stewart Sell ${ }^{1,2}$
}

\begin{abstract}
We systematically examined by immune histology the lungs of some widely used mouse models of asthma. These models include sensitization by multiple intraperitoneal injections of soluble ovalbumin (OVA) or of OVA with alum, followed by three intranasal or aerosol challenges 3 days apart. Within $24 \mathrm{~h}$ after a single challenge there is fibrinoid necrosis of arterial walls with deposition of immunoglobulin (lg) and OVA and infiltration of eosinophilic polymorphonuclear cells that lasts for about 3 days followed by peribronchial B-cell infiltration and slight reversible goblet cell hypertrophy (GCHT). After two challenges, severe eosinophilic vasculitis is present at $6 \mathrm{~h}$, increases by $72 \mathrm{~h}$, and then declines; B-cell proliferation and significant GCHT and hyperplasia (GCHTH) and bronchial smooth muscle hypertrophy recur more prominently. After three challenges, there is significantly increased induced bronchus-associated lymphoid tissue (iBALT) formation, GCHTH, and smooth muscle hypertrophy. Elevated levels of Th2 cytokines, IL-4, IL-5, and IL-13, are present in bronchial lavage fluids. Sensitized mice have precipitating antibody and positive Arthus skin reactions but also develop significant levels of IgE antibody to OVA but only 1 week after challenge. We conclude that the asthma like lung lesions induced in these models is preceded by immune complex-mediated eosinophilic vasculitis and iBALT formation. There are elevations of Th2 cytokines that most likely produce bronchial lesions that resemble human asthma. However, it is unlikely that mast cell-activated atopic mechanisms are responsible as we found only a few presumed mast cells by toluidine blue and metachromatic staining limited to the most proximal part of the main stem bronchus, and none in the remaining main stem bronchus or in the lung periphery.
\end{abstract}

Laboratory Investigation (2015) 95, 886-902; doi:10.1038/labinvest.2015.72; published online 1 June 2015

Nakajima et al, ${ }^{1}$ introduced an experimental model of asthma in mice using two intraperitoneal (i.p.) immunizations with ovalbumin (OVA) in alum followed by inhalation of aerosolized OVA. Since then many papers have been published using this model or variations of it (1,802 articles are listed in Pub Med under 'Ovalbumin Mouse Models of Asthma'; see reviews by Cohn, ${ }^{2}$ Zosky and Sly, ${ }^{3}$ Nials and Uddin, ${ }^{4}$ Kumar and Foster, ${ }^{5}$ and Mullane and Williams ${ }^{6}$ ). As pointed out by Kumar et al., 'There is no single 'classical' model, because numerous alternatives exist with respect to the choice of mouse strain, method of sensitization, route and duration of challenge and approach to assessing the host response.' The experimental approach that we utilized includes three phases: sensitization, resting, and challenge. Sensitization usually consists of multiple i.p. injections of soluble OVA over a 2- or 6-week period, but may also be accomplished by s.c. or i.p. injection, with alum. Then the mice are 'rested' for 7 to 40 days. Challenge is by intranasal (i.n.) injection or aerosol inhalation of soluble OVA, typically for three times with 3 days rest in between. Then 2 or 3 days after the last challenge, chemical, physiologic, or histologic analysis is used to evaluate the effects (for example, see Table 1). A prominent finding is increased airway resistance and enhanced respiratory pause after methacholine challenge (airway hyperresponsiveness (AHR) measured using a plethysmograph. ${ }^{8-10}$ Additional findings include: increased mononuclear cells and eosinophils in bronchial lavage fluid, goblet cell hypertrophy (GCHT) of the bronchial epithelium, peribronchial

${ }^{1}$ Division of Translational Medicine, Wadsworth Center, New York State Department of Health, Empire State Plaza, Albany, NY, USA and ${ }^{2}$ School of Public Health, University at Albany, Albany, NY, USA

Correspondence: Professor S Sell, MD, Division of Translational Medicine, Wadsworth Center, New York State Department of Health, Empire State Plaza, Wadsworth Center, PO Box 509, Room C-405, Albany, NY 12201, USA. E-mail: stewart.sell@health.ny.gov

IG carried out the experiments, obtained tissues, and performed all histological and immunostainings. SS evaluated all slides, took photomicrographs, and prepared the figures. Both authors contributed to the manuscript preparation.

Received 11 December 2014; revised 14 April 2015; accepted 15 April 2015 
Table 1 Summary of selected published results of experimental mouse models of ovalbumin (OVA)-induced asthma

\begin{tabular}{|c|c|c|c|c|}
\hline Mouse strain & Sensitization & Challenge & Result & References \\
\hline \multirow[t]{2}{*}{$\mathrm{BALB} / \mathrm{C}$} & $1 \mu \mathrm{g}$ OVA+alum, & $5 \%$ OVA aerosol 10-14 days & Eosinophil infiltration of trachea, peak at $24 \mathrm{~h}$; inhibition by & 1 \\
\hline & $2 \times$ in 2 weeks. & later; variable sacrifice times. & anti CD4 and anti-IL-5 antibodies. & \\
\hline \multirow[t]{2}{*}{$\mathrm{BALB} / \mathrm{C}$} & $10 \mu \mathrm{g}$ i.p. OVA $7 \times$ & 1 or 8 aerosol challenges 4 weeks & Immediate increase in airway responsiveness after challenge. & 15 \\
\hline & in 2 weeks; no alum. & later; sacrifice $24 \mathrm{~h}$ after last challenge. & & \\
\hline C57BL/6 & $10 \mu \mathrm{g}$ OVA i.p. with & Days 14-21 daily aerosol & BAL eosinophilia; peribronchial mixed infiltrate (monocytes, & 13 \\
\hline$I L-4-/-W / W^{V}$ & alum; single injection. & 1\% OVA; killed 1 day later. & lymphocytes, and eosinophils). Goblet cell hyperplasia, IL-4 & \\
\hline (mast cell def.); & & & dependent; mast cells not required. Class II/T cells required). & \\
\hline \multicolumn{5}{|l|}{$\mathrm{B} 6 . \mathrm{Aa}-/-$} \\
\hline \multirow[t]{2}{*}{$\mathrm{B} 6 \mathrm{D} 2 \mathrm{~F} 1 / \mathrm{J}$} & $8 \mu \mathrm{g}$ OVA in alum, & $0.5 \%$ OVA $\times 2$ aerosol, $6-20$ days & Blood and BAL fluid, eosinophilia in lung infiltrate, goblet cell & 16 \\
\hline & i.p., days 0 and 5 . & later. Variable sacrifice times. & hyperplasia, decreased by steroids. & \\
\hline C57BL/6 J, & $0.1 \mathrm{mg} / \mathrm{mouse}$ day 1 & $2 \%$ OVA aerosol 5 min, day 8; $1 \%$ & Early monocyte infiltrate followed by eosinophils and lymphocytes; & 17 \\
\hline RAG-1, P-selectin, & & aerosol, 20 min, days 15-21. & Mature CD4+ T cells required for lung eosinophilia. Goblet & \\
\hline CD4 and CD8 def. & & & cell hyperplasia. & \\
\hline \multirow[t]{2}{*}{$\mathrm{BALB} / \mathrm{C}$} & $10 \mu \mathrm{g}$ OVA i.p. or s.c., $7 \times$ & $20 \mu \mathrm{g}$ OVA i.t. on days 40 & Mononuclear and eosinophil infiltration in lungs. Formation & 11 \\
\hline & for 2 weeks, no alum. & 43, and 46. Killed 3 days later. & of BALT with IgE and IgA anti-OVA plasma cells. & \\
\hline \multirow[t]{2}{*}{$\mathrm{BALB} / \mathrm{C}$} & $10 \mu \mathrm{g}$ OVA i.p. $7 \times$ & 40 days after i.t. $20 \mu \mathrm{g}$ OVA & Eosinophils and monocytes in lung; hyperplasia of mucous & 18 \\
\hline & for 2 weeks; no alum. & $1 \times, 3 \times$, and $6 \times$ & cells before cells invade; fibrosis beneath basement membrane. & \\
\hline \multirow[t]{2}{*}{$\mathrm{BALB} / \mathrm{C}$} & $100 \mu \mathrm{g}$ OVA, $3 \times$ for & 1\% OVA aerosol; single & Eosinophilia in BAL and airway hyperresponsiveness. & 19 \\
\hline & 1 week dermal patch. & challenge; killed $24 \mathrm{~h}$ later. & & \\
\hline \multirow[t]{2}{*}{$\mathrm{BALB} / \mathrm{cj}$} & $25 \mu \mathrm{g}$ OVA s.c. in alum & $25 \mu \mathrm{g}$ OVA i.n. on days & Heterogeneous and increased airway responsiveness to & 20 \\
\hline & on days 1,7 , and 14 & $21-25$, killed on day 26. & methacholine challenge. & \\
\hline $\mathrm{BALB} / \mathrm{C}$ & $25 \mu \mathrm{g}$ OVA i.p. on & $25 \mu \mathrm{g}$ OVA i.n. on days & Chronic administration of beta-blockers reduces inflammation & 21 \\
\hline C57BL/6 J & days 1,7, and 14 & $21-25$, killed on day 26. & and mucous metaplasia. & \\
\hline $\mathrm{BALB} / \mathrm{C}, \mathrm{FVB} / \mathrm{N}$ & $25 \mu \mathrm{g}$ OVA i.p. on & $25 \mu \mathrm{g}$ OVA i.n. on days & Effects of $\beta 2-A R$ inverse agonists are caused by inhibition of & 22 \\
\hline B2-AR-Null & days 1,7 , and 14 & 41-45; killed on day 46. & B2-AR signaling pathway. & \\
\hline 129/BALB/C & $100 \mu \mathrm{g}$ OVA $3 \times$ for & 1\% OVA aerosol, single & CCR3 required for skin and lung eosinophilia; mast cell numbers & 14 \\
\hline CCR3 $-1-$ & 1 week dermal patch. & challenge; killed $24 \mathrm{~h}$ later & did not increase in WT mice. & \\
\hline \multirow[t]{2}{*}{$\mathrm{BALB} / \mathrm{C}$} & $10 \mu \mathrm{g}$ OVA in alum i.p. & $1 \%$ OVA in aerosol 3 or & Eosinophilia in BAL, goblet cell hyperplasia, and subepithelial & 23 \\
\hline & & 7 days for 1 or 6 weeks. & collagen deposition, chronically. & \\
\hline $\mathrm{BALB} / \mathrm{C} W \mathrm{~T}$ & $10 \mu \mathrm{g}$ OVA i.p. $2 \times$ & 1 week later; $100 \mu \mathrm{g}$ OVA i.n. $1 \times$ & Eosinophils in lung, hyperplasia of mucous cells. IL-17 dependent. & 24 \\
\hline T-Bet - /- & in alum for 2 weeks. & daily for 5 days; killed after $24 \mathrm{~h}$. & Histology of lung not described but pictures show BALT. & \\
\hline \multirow[t]{2}{*}{$\mathrm{BALB} / \mathrm{C}$} & $100 \mu \mathrm{g}$ OVA i.p. $2 \times$ & 1\% OVA for 22-28 days; killed on & DC-CTLA4lg reduces inflammation and increases Th1 and Treg cells. & 25 \\
\hline & on days 0 and 14 in alum. & day 29; passive transfer of DC-CTLA4lg. & & \\
\hline \multirow[t]{2}{*}{$\mathrm{BALB} / \mathrm{C}$} & $50 \mu \mathrm{g}$ OVA i.p. plus & $2 \%$ OVA i.t. on days 35 & IL-10 produced by CD4+ T cells increased neutrophils. & 12 \\
\hline & alum days 0,14 , and 28 . & 36,37 , and 40. & & \\
\hline \multirow[t]{2}{*}{$\mathrm{BALB} / \mathrm{C}$} & $50 \mu \mathrm{g}$ OVA i.p. plus & $5 \%$ OVA aerosol on days 22,26 & A phosphodiesterase (PDE-4) inhibitor (PDE-423) reduces & 26 \\
\hline & alum on days 0 and 12 & and 30; killed on day 31. & peribronchial inflammation. & \\
\hline \multirow[t]{2}{*}{$\mathrm{C} 57 \mathrm{Bl} / 6$} & $10 \mu \mathrm{g}$ OVA i.p. on days & $20 \mu \mathrm{g}$ OVA i.n. on days 40 & Inhibition of histamine-releasing-factor (HRF) reduces & 27 \\
\hline & $0,7,14,21,28$, and 35 & 43 , and 46. & peribronchial inflammation. & \\
\hline \multirow[t]{2}{*}{$\mathrm{BALB} / \mathrm{C}$} & $10 \mu \mathrm{g}$ OVA i.p. in & $1 \%$ OVA in aerosol, 3 days & Increased airway responsiveness. Increase in neutrophils, eosinophils, & 28 \\
\hline & alum, $2 \times$ in 2 weeks. & per week for 1, 24 , and 8 weeks. & etc in BAL. Many eosinophils in lung inflammation. & \\
\hline
\end{tabular}

def., deficient; i.n., intranasal; i.p., intraperitoneal; i.t., intratracheal; s.c., subcutaneous. 
mononuclear cell infiltrates in the lung, and development of bronchus-associated lymphoid tissue (BALT), ${ }^{11}$ as well as production of circulating immunoglobulin-E (IgE) antibody, a requirement for interleukins (IL)-4, IL-5, and IL-10 produced by CD4-Th2 cells, ${ }^{12,13}$ and reduction of effects if treated with beta-blockers. Interestingly, mast cells, a critical mediator of atopic asthma in humans, are not required ${ }^{13}$ and are not increased in lungs of affected mice. ${ }^{14}$

Many shortcomings of this model have been pointed out and pathologic descriptions of the pulmonary lesions reported. ${ }^{2,4-6}$ We now show for the first time that the major initiating pathologic change is immune complex-mediated eosinophilic vasculitis followed by formation of induced bronchus-BALT (iBALT). These changes precede pathologic changes in the bronchi consistent with asthma, including hyperplasia and hypertrophy of bronchial mucosa, peribonchial inflammation, and smooth muscle hypertrophy. A basic principle of pathology is that it is usually not possible to determine how a lesion started by examination of the lesion at a late stage. We could not find a systematic study of the early changes in the lung after a single or double pulmonary challenge. We now report that the lesions of the experimental mouse models of asthma are not initiated by mast cell degranulation but by immune complex eosinophilic vasculitis. Sensitized mice have precipitating antibody and Arthustype reactions when the skin was tested with OVA. In addition, although there are elevations of serum IgE antibody to OVA 1 week after the first challenge or after the second challenge, mast cells are only found in the most proximal part of the main stem bronchus and are not seen in the distal bronchus or peripheral lung of normal or sensitized and challenged mice.

\section{MATERIALS AND METHODS Mice}

Female BALB/c mice, 5-6 weeks old, were purchased from Taconic, Hudson, NY, USA, and acclimatized and housed in the Wadsworth Center's animal facility under controlled temperature and humidity in a $12 \mathrm{~h} \mathrm{light/dark}$ cycle. Purina lab chow and water were available ad libitum. Mice were 7-8 weeks old at the start of each study. All experimental protocols were approved by the Wadsworth Center Animal Care Committee according to the Animal Welfare Assurance Number A3183-01 of the National Institutes of Health. OVA was purchased from Sigma (catalogue number A5503).

\section{Experimental Design}

Three different protocols of sensitization and challenge of mice with OVA were followed, based on methods described in the literature.

\section{First Method}

A minor modification of the protocol of Hessel et al, ${ }^{15}$ was used. Mice were sensitized by i.p. injections of $10 \mu \mathrm{g}$ OVA in $100 \mu \mathrm{l}$ saline on alternate days for 2 weeks (seven injections) and then, 40 days after the beginning of sensitization, challenged i.n. with $25 \mu \mathrm{g}$ OVA in $50 \mu \mathrm{l}$ saline under anesthesia. Thirty-two mice were divided into three groups receiving one, two, or three challenges and two mice from each group killed at $6,24,72 \mathrm{~h}$, and 1 and 2 weeks after the challenge. Two control mice received $50 \mu$ l saline i.n. only. For skin testing, sensitized mice were injected in the shaved abdomen with saline on one side and $40 \mu \mathrm{g}$ OVA (in $20 \mu \mathrm{l}$ saline) on the other. Blood and bronchial-alveolar lavage (BAL) fluid were collected at euthanasia and then the mice were systemically perfused with $10 \mathrm{ml}$ PBS. Lungs were instilled with $1 \mathrm{ml} 4 \%$ paraformaldehyde (PFA) then immediately excised, placed in 4\% PFA, and dissected. Lungs and ovalbumin-injected skin were placed in one cassette; spleen, thymus, intestinal sections (Peyer's patches), and saline-injected skin were placed in a second cassette. Blood was clotted at $4^{\circ} \mathrm{C}$, spun down, and serum collected and stored at $-20^{\circ} \mathrm{C}$. In addition, in the second part of this experiment, eight sensitized mice were injected intravenously (i.v.) with $500 \mu \mathrm{g}$ OVA to determine if there might be a systemic reaction to antigen, such as anaphylactic shock. Anaphylactic shock was not elicited and no evidence of serum sickness was found.

\section{Second Method}

For this model, we followed the procedure published in the most recent report on the experimental asthma model that we could find, ${ }^{16}$ with slight modification. BALB/c mice, 8 weeks old at the time of first sensitization, received 6 i.p. injections of ovalbumin ( $10 \mu \mathrm{g}$ in $100 \mu \mathrm{l} 0.9 \%$ saline) once per week for 6 weeks and divided into three groups. Two to three mice were killed $6,24,48,72 \mathrm{~h}$, and 1 and 2 weeks after a single, double, or triple i.n. challenge with $25 \mu \mathrm{g}$ OVA in $50 \mu \mathrm{l}$ saline. All mice were skin tested $6 \mathrm{~h}$ prior to euthanasia and the tissues collected and processed as described above.

\section{Third Method}

This method was recently described as a short model that immunized with alum and did not use the extended sensitization period used in most of the models. ${ }^{17}$ Fourteen 6-weeks-old female BALB/c mice were given a single i.p. sensitization of $100 \mu \mathrm{g}$ of OVA in alum. On day 7, all mice were challenged i.n. with $100 \mu \mathrm{g}$ of OVA. Two mice each were sacrificed at each of the following times after a single challenge: 6, 24, 48, $72 \mathrm{~h}$, and 1 and 2 weeks. Controls included two sensitized mice that were not challenged and sacrificed at $24 \mathrm{~h}$ and two non-sensitized, unchallenged mice. Second and third challenges were not given.

\section{Blood, Cell, and Tissue Collection}

Blood was collected from the facial vein under full anesthesia and individual drops were used to make smears on glass slides. The remaining blood was allowed to clot, then centrifuged and the serum removed and stored at $-20^{\circ} \mathrm{C}$. The trachea was isolated, incised, and an 18 gauge, blunt-ended needle 
was inserted to collect BAL cells, following three instillations (500 $\mu \mathrm{l}$ each) of $0.9 \%$ saline, 2.6 mm EDTA. The three samples were pooled, red blood cells lysed with ammonium chloride buffer, and cytospins made on a Shandon cytocentrifuge. The systemic circulation was then perfused with $10 \mathrm{ml}$ saline via the left ventricle. For tissue examination, the lungs and various organs from four to six mice per time point were collected and fixed in freshly prepared 4\% PFA. Following automatic processing and embedding in paraffin, $5-\mu \mathrm{m}$ sections were placed on conventional glass slides for hematoxylin and eosin staining. These slides were screened and select tissue blocks recut into serial sections for immunohistochemical analysis.

\section{Blood Cytology}

Blood smears were air-dried then stored at room temperature. Smears were fixed in methanol, serially stained with MayGrunwald (catalogue number 63550), and Giemsa (catalogue number 48900), both purchased from Sigma-Fluka Chemical Company (St Louis, MO.) and differentiated with Sorensen's buffer, $\mathrm{pH}$ 6.8. In addition, smears were stained with modified Wright stain on a Hematek slide stainer. Differential counts were done microscopically under oil immersion by a certified hematology technician.

\section{BAL Cells}

To detect eosinophils, cytospins were dried overnight, fixed in methanol, serially stained with eosin and methylene blue/ toluidine blue $(0.06 \%$ and $0.04 \%$, respectively), then rinsed in tap water, and air dried. Mast cells were detected by a $1 \%$ toluidine blue solution (see below).

\section{BAL Fluid Cytokine Analysis}

Cytokines present in the BAL fluid were analyzed using a Luminex-based system. The panel of six cytokines (IL-2, IL-4, IL-5, IL-12, IL-13, and interferon- $\gamma$ ) was chosen to sample representative Th1 and Th2 cytokines and was purchased as a kit from R\&D Systems (Minneapolis, MN, USA). Following BAL lavage to collect cells, the pooled samples were centrifuged and the supernatants were decanted into cryotubes, and stored at $-80^{\circ} \mathrm{C}$ until analysis. Plates were prepared according to manufacturer's instructions using $50 \mu \mathrm{l}$ of BAL fluid and cytokine levels read on a Luminex machine. Duplicate samples were analyzed from each animal. Data were pasted into an Excel file and graphed within Excel.

\section{Histochemistry}

For eosinophil detection in tissues, we followed the method by Albert et al. ${ }^{18}$ Briefly, $5-\mu \mathrm{m}$ paraffin sections were rehydrated, stained $1 \mathrm{~h}$ in a $1 \%$ ethanolic solution of Congo Red (Sigma; catalogue \#C6767), counterstained in hematoxylin, and dehydrated and mounted in Permount (Fisher Scientific, Fair Lawn, NJ; catalogue \#SP15). For mast cells in tissues, two methods were used. Sections were stained either with an ethanolic 1\% toluidine blue (Polysciences, Warrington, PA, catalogue \#01234) solution diluted 1:10 in 1\% sodium chloride or by using the thionin technique, with thionin acetate (Sigma; catalogue \#T7029). Mucicarmine and periodic acid Schiff staining followed standard techniques, using ingredients purchased from Sigma (periodic acid; product \#P78750), J.T. Baker, St Louis, MO. (carmine; product number 3-E380), and MCB, Norwood, Ohio (basic fuchsin; product \#BX135).

\section{Immunohistochemistry}

Serial sections on charged glass slides were rehydrated through xylenes and ethanols to water, subjected to antigen retrieval and stained with various antibodies listed in Table 2 as described previously. ${ }^{19}$ Controls included sections treated with secondary peroxidase-labeled antibody only. Signals were developed with Extravidin-peroxidase (Sigma; catalogue \#E2886) and the chromogen was diaminobenzidine (Sigma; catalogue \#D8001). Labeling was amplified using biotinylated tyramine, following the method by Kerstens et al. ${ }^{20}$ Images were captured on an Olympus microscope, model BX51, equipped with a digital camera and Optronics Version 1.2 software. All slides were evaluated by a board certified pathologist (SS). Control immunoperoxidase staining is shown in Supplementary Figure 1.

\section{Immunodiffusion}

Gel preparation and staining followed the method by Hornbek. ${ }^{21}$ Ouchterlony plates were generated on conventional $1^{\prime} \times 3^{\prime}$ glass slides, with an underlayer of $0.5 \%$ agar (Difco Noble agar; catalogue \#0142-01), and a top layer of $2 \%$. Polyclonal rabbit anti-ovalbumin (catalogue \#1221) was purchased from Abcam, Cambridge, MA. Samples were pipetted into punch wells and the slides incubated $48 \mathrm{~h}$ at room temperature in a humidified chamber. Gels were stained with 0.5\% Coomassie Brilliant Blue R250 (Bio-Rad Laboratories, Richmond, CA; catalogue number 161-0406), destained in 5\% glacial acetic acid, $15 \%$ ethanol, then airdried and photographed.

\section{IgE Assay}

IgE antibody to OVA in sera and BAL fluid was assayed with an ELISA kit for OVA-specific IgE (Chondrex, Redmond, WA; kit number 3010), following the manufacturer's directions. The OVA-specific antibody was a rat monoclonal, clone 77-1. A Bio-Tek micro-plate reader, model EL808 was used to read the plate at $450 \mathrm{nM}$.

\section{Statistics}

Statistical differences in means were determined by one-way analysis of variance with Tukey's honest significant difference test.

\section{RESULTS}

Histologic grading of the lung lesions at $48 \mathrm{~h}$ from a total of eight experiments using three different models is summarized in Table 3. There is no identifiable qualitative difference in the 
Table 2 Antibodies used to label tissue sections

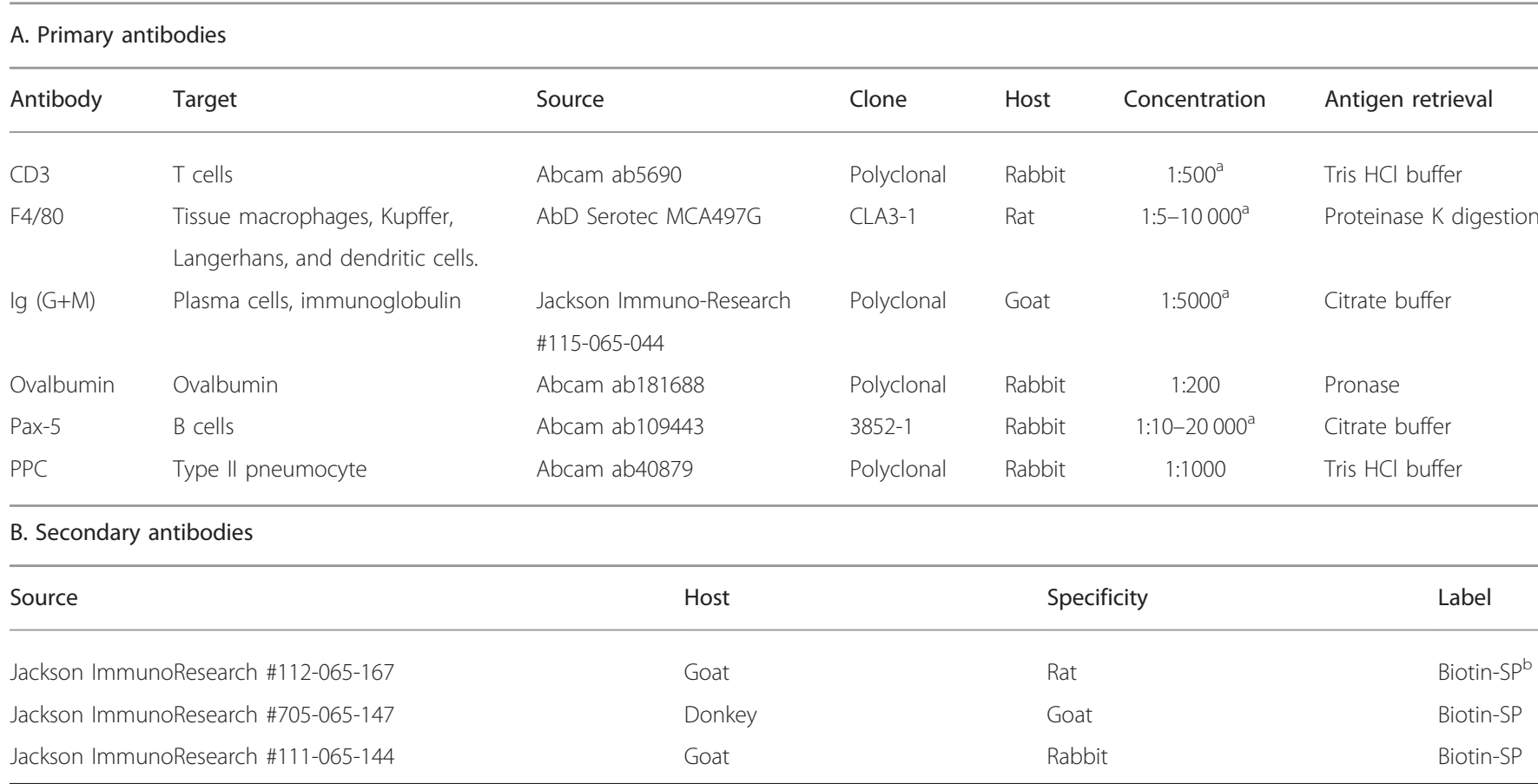

PPC, prosurfactant protein C. ${ }^{a}$ Amplified with biotinylated tyramine (see text for details). ${ }^{b} d$-Biotinyl-ź-aminocaproic acid-NHS-ester.

Table 3 Average histologic grade of reactions (0 to 3 ) at $48-72 \mathrm{~h}$

\begin{tabular}{|c|c|c|c|c|c|c|c|c|c|}
\hline Exp. & Reference & Brief description & Total \#mice & Challenges & $\begin{array}{l}\text { Fibrinoid } \\
\text { necrosis }\end{array}$ & PMNs & $\begin{array}{l}\text { Perivascular } \\
\text { round cells }\end{array}$ & $\begin{array}{l}\text { Peribronchial } \\
\text { round cells }\end{array}$ & iBALT \\
\hline & & challenges 6,9 , and 12 days later & 5 & 2 & 1.0 & 2.1 & 2.8 & 2.1 & 1.4 \\
\hline & & & 3 & 3 & 0.3 & 1.1 & 3.0 & 3.0 & 2.7 \\
\hline & & & 6 & 3 & 0.8 & 0.9 & 3.0 & 2.8 & 2.8 \\
\hline \multirow[t]{2}{*}{3} & 29 & Sensitization one high dose with & 4 & 1 & 2.5 & 2.8 & 0 & 1.0 & 0 \\
\hline & & alum; challenge 7 days later & & & & & & & \\
\hline
\end{tabular}

response to challenge after the various sensitization protocols, so that our observations are pooled for presentation.

Vascular and peribronchial inflammation after single, double, and triple challenge is shown by H\&E staining in Figure 1 (See also Table 4). After a single challenge (Figure 1, top row), vascular fibrinoid necrosis with polymorphonuclear cell (PMN) infiltrate appears at $24 \mathrm{~h}$ and by $72 \mathrm{~h}$ begins to change from eosinophilic PMN to mononuclear and shift from perivascular to peribronchial. By 2 weeks, the inflammation has largely subsided, but a small cuff of peribronchial mononuclear cells can be seen (pictures not included). After double challenge (Figure 1, second row), increased fibrinoid necrosis with eosinophilic PMNs is seen at $6 \mathrm{~h}$ through $48 \mathrm{~h}$. By $72 \mathrm{~h}$, the infiltrate contains a majority of mononuclear cells with many fewer PMNs. Perivascular and then peribronchial mononuclear infiltration is greater than after a single challenge but is also resolving by 2 weeks. After triple challenge (Figure 1, third row), there is little, if any, fibrinoid necrosis and very little vascular infiltrate with PMNs. Instead, the most striking change is perivascular and peribronchial mononuclear cell infiltration over 30 cells wide around vessels adjacent to bronchi as well as a mixed mononuclear infiltrate 


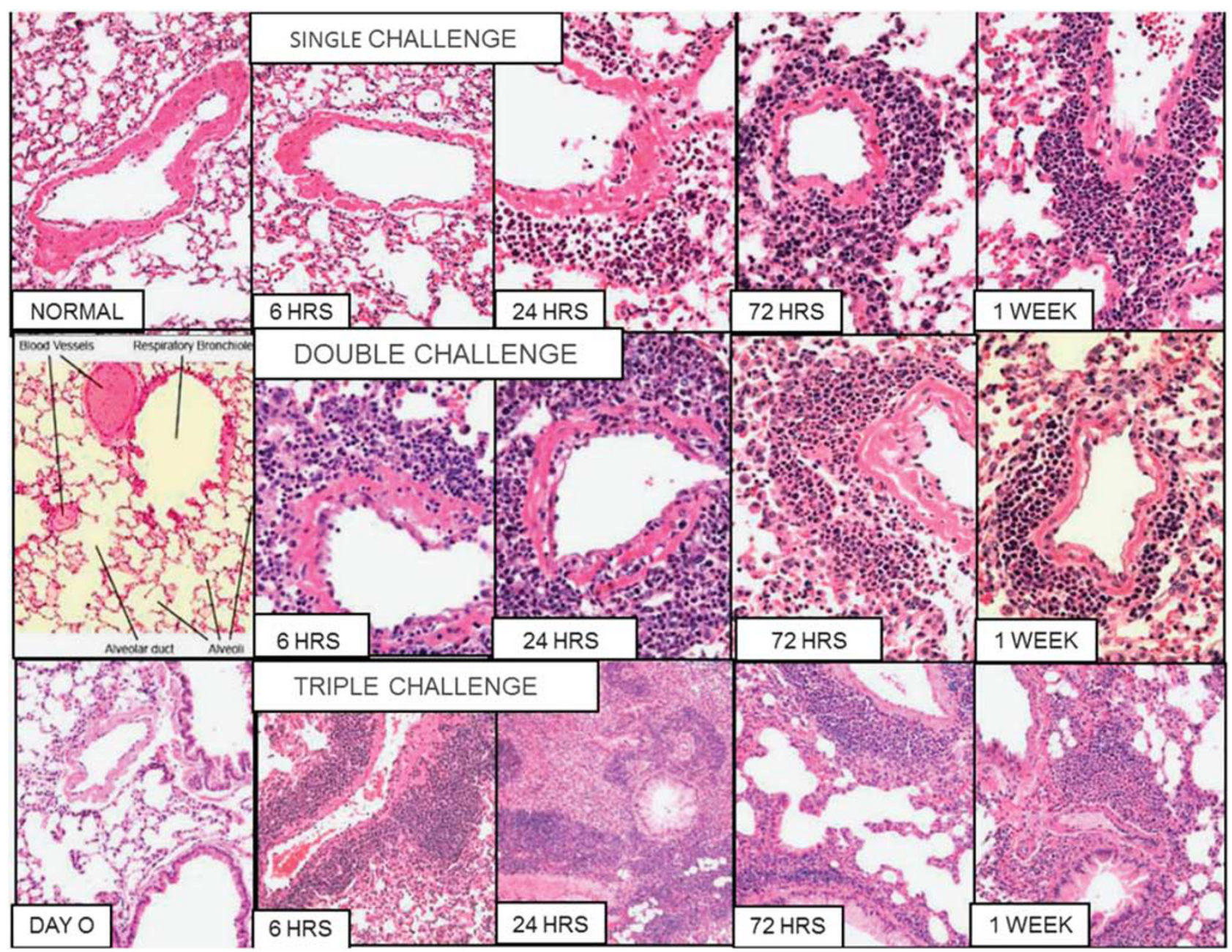

Figure 1 Vascular and bronchial inflammation in ovalbumin sensitized mice. Pictures $(\times 100$ and $\times 200)$ of H\&E stained microscopic slides after single (first row), double (second row), and triple (third row) i.n. ovalbumin (OVA) challenges of OVA sensitized mice. Normal and day 0 (before the third challenge) are shown in the first column for comparison. At $6 \mathrm{~h}$ after a single challenge, there is essentially no change in pulmonary arteries from normal. However, after a second challenge there is severe fibrinoid necrosis and polymorphonuclear infiltrate. After three challenges, there is little fibrinoid necrosis but a marked perivascular infiltrate of mononuclear cells. After one and two challenges, the vasculitis resolves with slight residual round cell infiltrate. However, after three challenges there is extensive iBALT formation at 24-72 $\mathrm{h}$ that then resolves over the next 2 weeks. H\&E, hematoxylin and eosin; iBALT, induced bronchial associated lymphoid tissue; i.n., intranasal.

in the alveoli reaching a peak at $24-72 \mathrm{~h}$, then decreasing by 1 week.

\section{Bronchial Lesions}

Increasing bronchial mucosal hyperplasia and hypertrophy as well as bronchial muscular hypertrophy seen after tracheal challenge are shown in Figure 2, and statistical analysis of measurements of changes in Table 5. Minimal changes occur as early as $48 \mathrm{~h}$ after a single challenge (Figures $2 \mathrm{e}-\mathrm{h}$ ) but these quickly resolve if there is no further challenge. Significant submucosal muscle hypertrophy, as well as bronchial mucosal hyperplasia, and hypertrophy peak about $48-72 \mathrm{~h}$ after the second and third challenges (Figures $2 \mathrm{i}-\mathrm{k}, \mathrm{m}-\mathrm{O}$ ). These gradually decrease so that by 2 weeks only a few focal areas remain.

\section{Eosinophilic Vasculitis}

To confirm the nature of the PMNs in the acute vasculitis and peribronchial inflammation, tissues from each challenge and time point were stained with Congo Red. Selected examples of the results are shown in Figures 3a-f. Twenty-four to $48 \mathrm{~h}$ after a single (not shown) or double challenge most of the perivascular infiltrate is eosinophilic PMNs (Figures $3 a$ and $b$ ). By $72 \mathrm{~h}$ (Figure 3c), there is an increasing number of mononuclear cells and by 1 week (Figure 3d) most of the perivascular cells are mononuclear. However, even after three challenges, when most of the perivascular and peribronchial 
Table 4 Histopathologic grading of lesions in lungs

\begin{tabular}{|c|c|c|c|c|}
\hline \multirow[b]{2}{*}{ No. challenges } & \multicolumn{4}{|c|}{ Time after pulmonary challenge } \\
\hline & $6 \mathrm{~h}$ & $24 \mathrm{~h}$ & $72 \mathrm{~h}$ & 1 week \\
\hline \multicolumn{5}{|c|}{ Necrotizing vasculitis } \\
\hline 1 & 0 & + & ++ & + \\
\hline 2 & ++ & +++ & ++ & + \\
\hline 3 & + & + & + & 0 \\
\hline \multicolumn{5}{|c|}{ Perivascular round cell infiltrate } \\
\hline 1 & 0 & 0 & + & + \\
\hline 2 & ++ & ++ & +++ & ++ \\
\hline 3 & +++ & ++++ & ++++ & +++ \\
\hline \multicolumn{5}{|l|}{ BALT formation } \\
\hline 1 & 0 & 0 & + & + \\
\hline 2 & + & ++ & +++ & ++ \\
\hline 3 & ++ & +++ & ++++ & +++ \\
\hline \multicolumn{5}{|c|}{ Goblet cell hypertrophy and hyperplasia (GCHTH) } \\
\hline 1 & 0 & 0 & + & 0 \\
\hline 2 & + & ++ & +++ & + \\
\hline 3 & +++ & ++++ & ++++ & ++ \\
\hline
\end{tabular}

$\mathrm{H}+\mathrm{E}$-stained slides were coded and read by a board certified pathologist. Grading was from 0 (normal) to +++++ (highest level of infiltrate).

inflammation is mononuclear (see Figure 4), eosinophils are seen in the submucosa and lumen of the bronchi (Figures $3 \mathrm{e}$ and $\mathrm{f}$ ).

\section{Mast Cells}

Mast cells in the lung are limited to the first high-power microscopic field between the trachea and the main stem bronchus (Figures 3g-j). Mast cells are not seen in either the remaining main stem bronchus or the peripheral lung of normal or sensitized and challenged mice. The number of mast cells per section ranged from 0 to 4 in normal mice to 0 to 3 after 1 challenge, 1 to 5 after 2 challenges, and 0 to 6 after 3 challenges. Thus, mast cells may be focally increased at the tracheobronchial junction after challenge but the differences are not statistically significant.

\section{Immunostaining for Ig and OVA}

Six hours after one challenge, faint deposits of Ig and OVA are visible next to small vessels (see Figure 4 and Supplementary Figure 2). By $24 \mathrm{~h}$, Ig deposits increase around small vessels and OVA is seen next to inflamed vessels, but OVA is mostly in alveolar macrophages (Figures $4 \mathrm{~b}$ and $\mathrm{c}$ ). At later time points, Ig is localized in cells around inflamed vessels and staining for OVA is negative. Staining for complement is not seen so that although the deposition if Ig and OVA is consistent with immune complexes, this cannot be proven at this time. Later cellular staining may be due to uptake of Ig by inflammatory cells or presence of Ig containing plasma cells. Staining for complement was not possible in the formalinfixed paraffin-embedded sections.

\section{iBALT Formation}

The evolution of iBALT formation is shown in Figure 5. The peribronchial collections of mononuclear cells first seen at $72 \mathrm{~h}$ after a single challenge are made up mostly of Pax $5+\mathrm{B}$ cells (Figure $5 \mathrm{~b}$ ) with a scattering of $\mathrm{CD} 3+\mathrm{T}$ cells (Figure $5 \mathrm{c}$ ) and few eosinophils (Figure 5d). Similar peribronchial B-cell collections are seen $6 \mathrm{~h}$ after a second challenge, which is not surprising, since the second challenge is given 3 days after the first. By $72 \mathrm{~h}$ after the second injection, the peribronchial B cell form ball-like masses (Figures $5 i$ and $j$ ) that are distinct from adjacent inflammation, which is still eosinophilic (Figure 5l). After the third challenge (Figures $5 \mathrm{~m}-\mathrm{q}$ ), wellformed follicles containing Pax5+, Ig- B-cells zones, and Pax5 -, Ig+ (plasma cell) zones along with adjacent alveolar mixed mononuclear cell infiltrates predominate. In fact, most of the inflammatory change is composed of dense collections of B cells that appear to arise in vascular areas next to bronchi. After three challenges, focal collections of iBALT are still seen at 2 weeks, but in general all changes are substantially reduced from the peak at $24 \mathrm{~h}$ (Figure 1; bottom row, Table 3).

\section{BAL Fluid Cells}

Staining and percentage of cell types in BAL is shown in Figures $6 \mathrm{a}-\mathrm{d}$. The total cell count rose from $3 \times 10^{4}$ on day 0 to $4.5 \times 10^{5}$ on day 1 , then declined gradually to $9 \times 10^{4}$ at 2 weeks. One day following i.n. challenge there is a marked increase in cells with a corresponding increase in the percentage of neutrophils and eosinophils with a decrease in monocytes. By day 3, the percentage of eosinophils increases to over $50 \%$ while the percentage of monocytes drops (Figure 6e). In addition, there is a marked increase in the number and size of monocyte cytoplasmic vacuoles. The percentage of eosinophils remains high for 1 week and then drops to pre-challenge levels at 2 weeks after challenge. Similar changes were recorded after triple challenge, but fewer time points are available.

\section{Peripheral Blood Cells}

The percentage of various white blood cells is shown in Supplementary Table 1 . The only significant changes from normal or unchallenged mice is slightly, but significantly, elevated eosinophils in method 2 after two or three challenges and in method 3 after one challenge. 

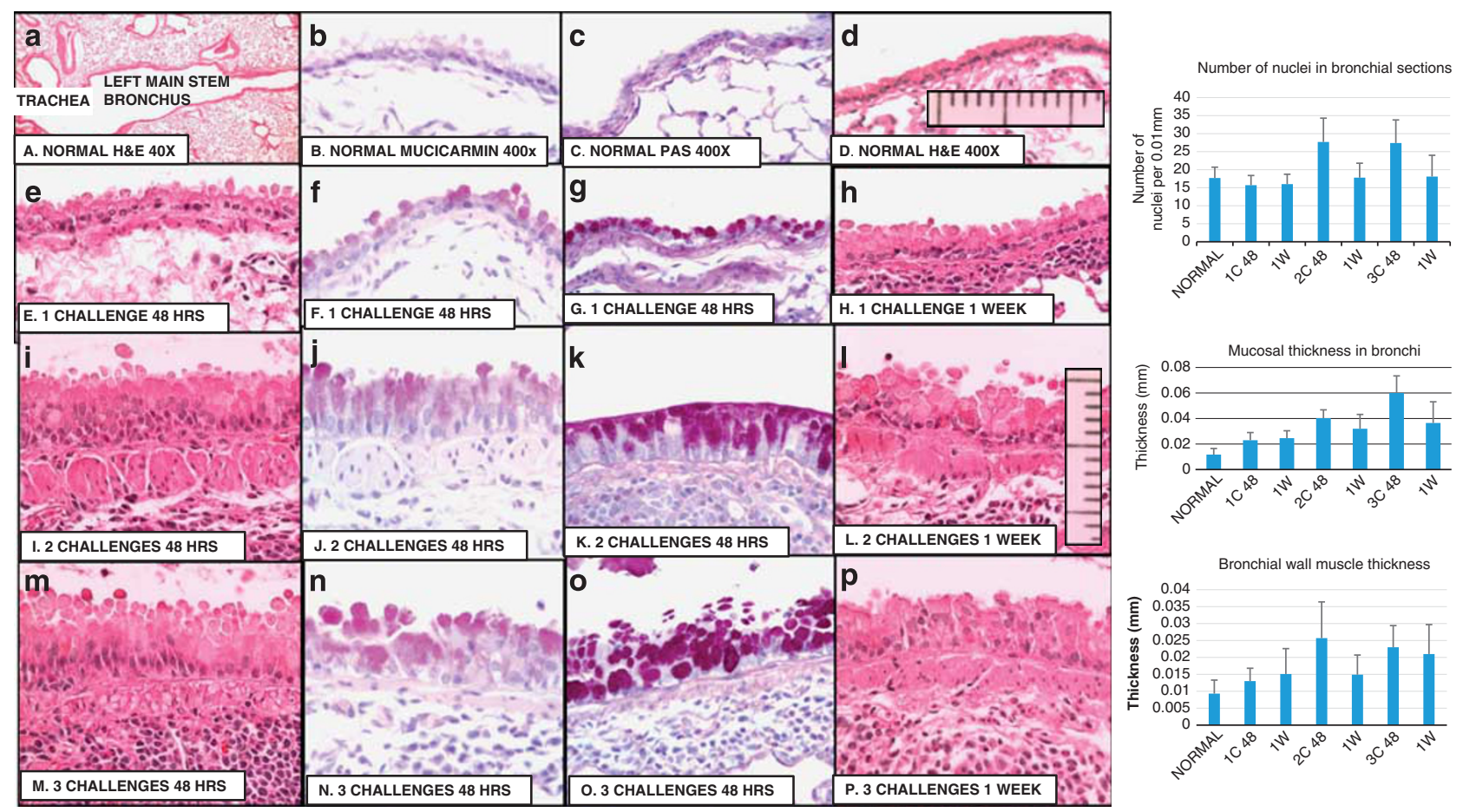

Figure 2 Bronchial mucosal lesions. (a) $\times 40$; (b-p) $\times 400$. (a-d) normal lung. (e-h) one challenge; (i-I) two challenges, $(\mathbf{m}-\mathbf{p})$ three challenges. (a) Shows selection of tissue section including left main stem bronchus where changes can be measured accurately. $\mathbf{d}$ and $\mathbf{I}$ includes ocular micrometer scale used to count nuclei and measure thickness of mucosa and submucosal muscle. Table 5 shows the measurements and statistical analysis. Clearly by the second challenge, there are lesions associated with asthma including mucosal hyperplasia and hypertrophy, and hypertrophy of submucosal smooth muscle. There is a significant increase in mucosal cell nuclei at $48 \mathrm{~h}$ after two or three challenges $(P<01)$ in mucosal thickness and submucosal smooth muscle thickness after each challenge $(P<01)$ as well as significant increases from one challenge to the next.

\section{IgE Antibody to OVA}

The titers of IgE antibody to OVA in three to six mice $48 \mathrm{~h}$ and 1 week after one, two or three challenges are shown in Figure $6 f$. There is no elevation over normal in sensitized but unchallenged mice. There is a significant difference after each challenge, with levels reaching five times those of unchallenged mice after three challenges.

\section{Precipitating Antibody and Arthus Reaction}

The serum of each mouse tested positive for precipitating antibody by double diffusion in agar (Figure 7a). Six hours after an injection of $40 \mu \mathrm{g}$ of OVA into the shaved skin of each of the sensitized mice there is a grossly indurated and erythematous skin lesion (Figure $7 \mathrm{~b}$ ) associated with focal PMNs around small subdermal vessels (Figures $7 \mathrm{c}$ and $\mathrm{d}$ ), as well as diffuse PMN infiltration beneath the dermal muscle layer. No microscopic inflammation is seen in non-sensitized control mice or skin sites of sensitized mice injected with saline. Congo Red staining (Figure 7d) reveals that most of the cells are neutrophilic PMNs, with only a few eosinophils; staining for $\mathrm{T}$ and $\mathrm{B}$ cells is essentially negative, but a few macrophages identified by F4/80 staining are seen (not shown). Mast cells are clearly seen in areas of the skin not involved in inflammation (Figure 7c, insert) and are not increased in the sensitized mice. Both OVA and Ig (Figures 7e and $\mathrm{f}$, respectively) are present in the perivascular lesions in the skin consistent with formation of immune complexes. We did not see an immediate skin reaction as described by Saloga et $a .^{22}$ that they observed after skin testing of mice sensitized by 10 consecutive inhalations of OVA.

\section{Cytokines}

There is a significant elevation of IL-5 $48 \mathrm{~h}$ after the first challenge and of IL-13 after all three challenges in mice sensitized according to method 2 (Supplementary Figure 3). In addition, IL- 4 is elevated $24 \mathrm{~h}$ after challenge in the short model of sensitization (data not shown). The levels of the other cytokines measured (IL-12, IL-2, and INF- $\gamma$ ) are not elevated.

\section{DISCUSSION}

According to the Mayo Clinic, asthma is a condition in which airways narrow and swell and produce extra mucus. This can make breathing difficult and trigger coughing, wheezing, and shortness of breath. According to the National Library of Medicine, asthma is a respiratory condition marked by spasms in the bronchi of the lungs, causing difficulty in breathing. It usually results from an allergic reaction or other forms of hypersensitivity, leading to reversible airway obstruction, airway hyperactivity, and airway inflammation. These and 
Table 5 Goblet cell hyperplasia and hypertrophy and bronchial smooth muscle hypertrophy

A. Number of nuclei per $0.01 \mathrm{~mm}$ in cross-sections of bronchial epithelium in OVA-exposed mice

\begin{tabular}{|c|c|c|c|c|c|c|c|}
\hline & Untreated & $1 C, 48 \mathrm{~h}$ & 1C, 1 week & $2 C, 48 \mathrm{~h}$ & $2 \mathrm{C}, 1$ week & $3 C, 48 \mathrm{~h}$ & 3C, 1 week \\
\hline$n$ & 11 & 11 & 9 & 19 & 14 & 12 & 12 \\
\hline Mean & 17.7 & 15.7 & 16 & 27.7 & 17.8 & 27.4 & 18.1 \\
\hline s.d. & 3 & 2.7 & 2.7 & 6.6 & 4 & 6.4 & 5.9 \\
\hline ANOVA, Tukey HSD & - & NS & NS & $P<0.01^{*}$ & NS & $P<0.01^{*}$ & NS \\
\hline
\end{tabular}

B. Mucosal thickness $(\mathrm{mm})$

\begin{tabular}{|c|c|c|c|c|c|c|c|}
\hline & Untreated & $1 \mathrm{C}, 48 \mathrm{~h}$ & 1C, 1 week & $2 \mathrm{C}, 48 \mathrm{~h}$ & 2C, 1 week & $3 \mathrm{C}, 48 \mathrm{~h}$ & 3C, 1 week \\
\hline$n$ & 18 & 19 & 15 & 30 & 35 & 30 & 30 \\
\hline Mean & 0.0117 & 0.023 & 0.0246 & 0.0403 & 0.032 & 0.06 & 0.0365 \\
\hline s.d. & 0.0048 & 0.006 & 0.0058 & 0.0065 & 0.0112 & 0.0134 & 0.0166 \\
\hline ANOVA, Tukey HSD & - & $P<0.01$ vs UNT & $P<0.01$ vs UNT; $P<0.01$ vs $1 C 48 \mathrm{~h}$ & $P<0.01$ vs UNT & $P<0.01$ vs UNT; $P<0.05$ vs $2 C 48 \mathrm{~h}$ & $P<0.01$ vs UNT & $P<0.01$ vs UNT; $P<0.01$ vs $3 C, 48 \mathrm{~h}$ \\
\hline \multicolumn{8}{|c|}{ C. Submucosal smooth muscle thickness (mm) } \\
\hline & Untreated & $1 \mathrm{C}, 48 \mathrm{~h}$ & 1C, 1 week & $2 \mathrm{C}, 48 \mathrm{~h}$ & 2C, 1 week & $3 \mathrm{C}, 48 \mathrm{~h}$ & 3C, 1 week \\
\hline$n$ & 18 & 20 & 15 & 25 & 36 & 30 & 30 \\
\hline Mean & 0.0093 & 0.013 & 0.0151 & 0.0257 & 0.0149 & 0.023 & 0.021 \\
\hline s.d. & 0.004 & 0.0038 & 0.0075 & 0.0107 & 0.0058 & 0.0064 & 0.0087 \\
\hline ANOVA, Tukey HSD & - & $P<0.05$ vs UNT & $P<0.05$ vs UNT; $P<0.05$ vs $1 C, 48 \mathrm{~h}$ & $P<0.01$ vs UNT & $P<0.05$ vs UNT; $P<0.01$ vs $2 C, 48 \mathrm{~h}$ & $P<0.01$ vs UNT & $P<0.05$ vs UNT; $P<0.05$ vs $3 C, 48 \mathrm{~h}$ \\
\hline
\end{tabular}

C, challenge; $n$, number of separate microscopic fields counted per treatment; NS, not significant; s.d., standard deviation.

*, compared with untreated.

other functional descriptions of asthma include a broad spectrum of conditions that may be useful clinically, but essentially ignore various possible differences in pathologic mechanisms and tissue pathology. Human acute asthma, for example, is included in the immunopathologic category of atopic or anaphylactic reactions unleashed when allergen reacts with and cross-links with IgE receptors on mast cells. ${ }^{23}$ Repeated activation of this mechanism results in the pathologic features of chronic human asthma: hyperplasia of bronchial smooth muscle, hyperplasia of bronchial mucous cells, chronic peribronchial inflammation with increased mast cells, and thickening of the basement membrane of the bronchial mucosa. ${ }^{23}$ Herein, we show that the ovalbumin mouse model of asthma has features of immune complex disease, which cast doubt on its validity as a model for asthma. Bronchial lesions consistent with asthma (mucosal hyperplasia and hypertrophy, and hyperplasia of bronchial smooth muscle) are preceded by immune complex vasculitis and iBALT formation. It is not clear why lesions typical of asthma are induced by an immune complex reaction; elevation of Th2-type cytokines that induce asthma-like inflammation is seen but these are not usually associated with Th1-type immune complex reactions. Elevations of serum $\operatorname{IgE}$ suggest that some atopic-like Th2 mechanism may become active after the initial Th1 reaction, but the lack of mast cells in most of the major bronchus and lung periphery rule against this.

\section{Immune Complex Eosinophilic Vasculitis}

The early lesions induced by a single injection of antigen into the lung of mice sensitized to produce the mouse model of asthma are fibrinoid necrosis of arterial walls and infiltration of eosinophilic PMNs. There is no evidence of acute bronchial constriction or mucous hyperplasia characteristic of acute human asthma at this time, although hyperplasia and hypertrophy of mucous cells begins about 3 days after primary challenge. We consider the acute vasculitis to be immune complex mediated except that the inflammatory cells are up to $70 \%$ eosinophilic PMNs rather than neutrophilic. Mice sensitized by multiple OVA injections or a single injection in alum demonstrate Arthus skin reactions ${ }^{24}$ when the skin is tested by injection of OVA. The sera of these mice contain high titers of precipitating antibody as detected by 


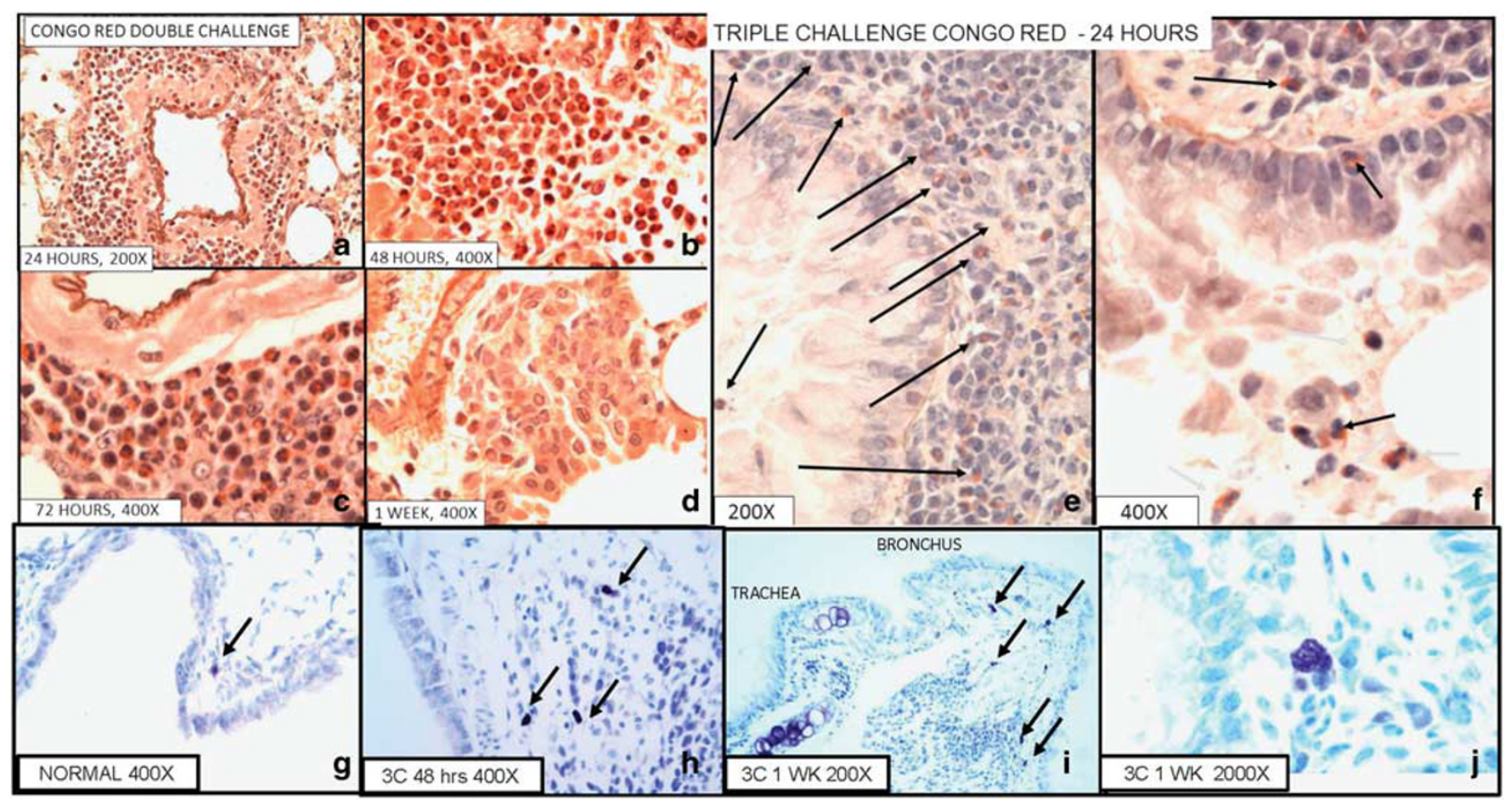

Figure 3 Eosinophilic inflammation and mast cells. (a-d) Demonstration of eosinophilic vasculitis by Congo Red stain after double challenge and (e and f) bronchial eosinophilia $24 \mathrm{~h}$ after triple challenge. (g-j) Mast cells in normal and challenged mice. (a-d) Double challenge at (a) $24 \mathrm{~h}$, (b) $48 \mathrm{~h}$, (c) $72 \mathrm{~h}$, and (d) 1 week. (e and f) Bronchi $24 \mathrm{~h}$ after triple challenge. b shows high percentage of Congo Red-positive eosinophils at day 2 and $\mathbf{c}$ shows lesser numbers of eosinophils and more mononuclear cells. These are replaced by round cells by 1 week (d). Only a few eosinophils remain by day 14 (not shown). e and $\mathbf{f}$ show eosinophils in bronchi after three challenges. There are few perivascular eosinophils after three challenges (see Figure 3). (g) $\mathrm{A}$ mast cell in normal lung. (h) Three mast cells $48 \mathrm{~h}$ after triple challenge. (i) Low magnification showing five mast cells in proximal left main stem bronchus. (j) High magnification of mast cell. Mast cells are only found in the most proximal main stem bronchus and not in lung periphery in both normal, sensitized, as well as sensitized and challenged mice. Arrows in $\mathbf{e}$ and $\mathbf{f}$ point to eosinophils; arrows in $\mathbf{g}$-i point to mast cells.

double-diffusion-in-agar, and both Ig and OVA are present in the vascular lesions of the skin as well as the vascular lesions of the lung. Immune complex vasculitis has been repeatedly demonstrated when soluble protein antigen is injected into the trachea of experimental animals either actively or passively immunized with antibody to the antigen.

\section{Active Pulmonary Arthus Reactions}

Active Arthus reactions in the lung were employed from 1912 to 1972 to determine the effect of immune complex-induced injury. ${ }^{25-32}$ This involved active immunization followed by pulmonary challenge with antigen. For example, Schlecht and Schwenke ${ }^{25}$ saw pulmonary hemorrhage and acute alveolitis in immunized guinea pigs after inhalation of horse serum. Opie, ${ }^{26}$ repeated the approach in the lung originally described by Arthus in 1903 for the skin. In rabbits that had been immunized by repeated injections of horse serum, injection of horse serum into the lung produced 'an acute localized consolidation with leucocytes and edema surrounding a central focus of necrosis.' Most of Opie's studies were done on skin reactivity where he found that the reaction depends on the titer of precipitating antibody. In rabbits immunized to ovalbumin, Cannon and Walsh ${ }^{28}$ describes alveolitis and bronchitis featuring vasculitis, but the histologic findings are not described. Fried ${ }^{27}$ observed an influx of 'granulocytes' 12 to $15 \mathrm{~h}$ after intratracheal injection of horse serum into immunized rabbits. Eosinophils were also seen regularly, but 'on rare occasions'. The reaction peaked at 24 to $36 \mathrm{~h}$ and then gradually subsided. This is essentially what we describe in OVA-sensitized mice following a single i.n. injection of OVA, except for the predominance of eosinophils seen in our study. The suggestion that active Arthus reactions in the lung might have similarities to asthma was made by Kallos and Kallos, ${ }^{33}$ on the basis of an influx on eosinophils in the lungs of sensitized and challenged guinea pigs (see also the study by Kung et al. ${ }^{34}$ ). However, Sanjar et al. ${ }^{35}$ noted that there is no evidence for a causal relationship between increased airway reactivity and eosinophilia in this model. The application of this model has extended to two divergent approaches: (i) using passive reverse Arthus reactions in the lung to study the mechanisms involved in immune complex inflammation, and (ii) in mice as a model for asthma.

\section{Reverse Passive Arthus Reactions in the Lung}

A number of laboratories have used a reverse passive Arthus reaction in the lung introduced by Ward and co-workers ${ }^{36-40}$ 
to identify components of the early immune complex initiated inflammatory reaction. The standard protocol for this model is to inject antibody into the trachea followed within minutes by injection of antigen (bovine serum albumin or OVA) i.v. Within 4 to $6 \mathrm{~h}$, a neutrophil-rich exudate develops in alveolar and interstitial areas and then gradually fades. Deposits of antigen and antibody may be identified in the involved areas. Antibody, complement (C3), neutrophils, and release of oxygen radicals are required. ${ }^{36}$ The inflammatory lesions are not localized perivascularlly as in the model described in the asthma models in this paper, since the antibody-antigen reaction takes place in the airway and not the vasculature. This inflammation is blocked by superoxide dismutase, ${ }^{37}$ but enhanced by tumor necrosis factor (TNF) released from resident macrophages. ${ }^{38}$ It requires interaction between neutrophils and endothelial cells mediated by endothelial-leukocyte adhesion molecule $1,{ }^{39} \beta_{2}$ integrins, ${ }^{40}$ and endothelins, $\mathrm{C} 3$ and mast cells, ${ }^{41}$ urokinase/urokinase receptors, ${ }^{42}$ Fc $\gamma$ R-mediated TNF- $\alpha$ and CXCR2 ligand (CXCR2L) production, ${ }^{43}$, and $\mathrm{G}_{\mathrm{i} 2}$ protein-coupled $\mathrm{C} 5 \mathrm{a}$ receptor, which regulates IgG FcR function and enhances transmigration of neutrophils into inflammatory lesions. ${ }^{44}$ The key is the early C5aR-Gi-dependent signal for Fc $\gamma$ RIII activation, local synthesis of TNF- $\alpha$ and CXCR2L leading to recruitment of PMNs. The factors responsible for eosinophilic infiltration in our studies are under investigation.

Why eosinophilic vasculitis? Most of the studies using the mouse models of asthma describe a marked increase in eosinophils, in bronchial lavage fluid, ${ }^{45}$ but not a significant increase in the peripheral blood ( 0 in controls to up to $0.1 \%$ in blood after challenge), whereas there is a marked increase in neutrophils in the blood (from $16 \%$ in controls to $28 \%$ in sensitized and three times challenged mice). ${ }^{46}$ This is more consistent with a Th1-type response (immune complex) than a Th2-type response (atopic). The precise role of eosinophils in asthma is not clear. They may only be bystander cells or

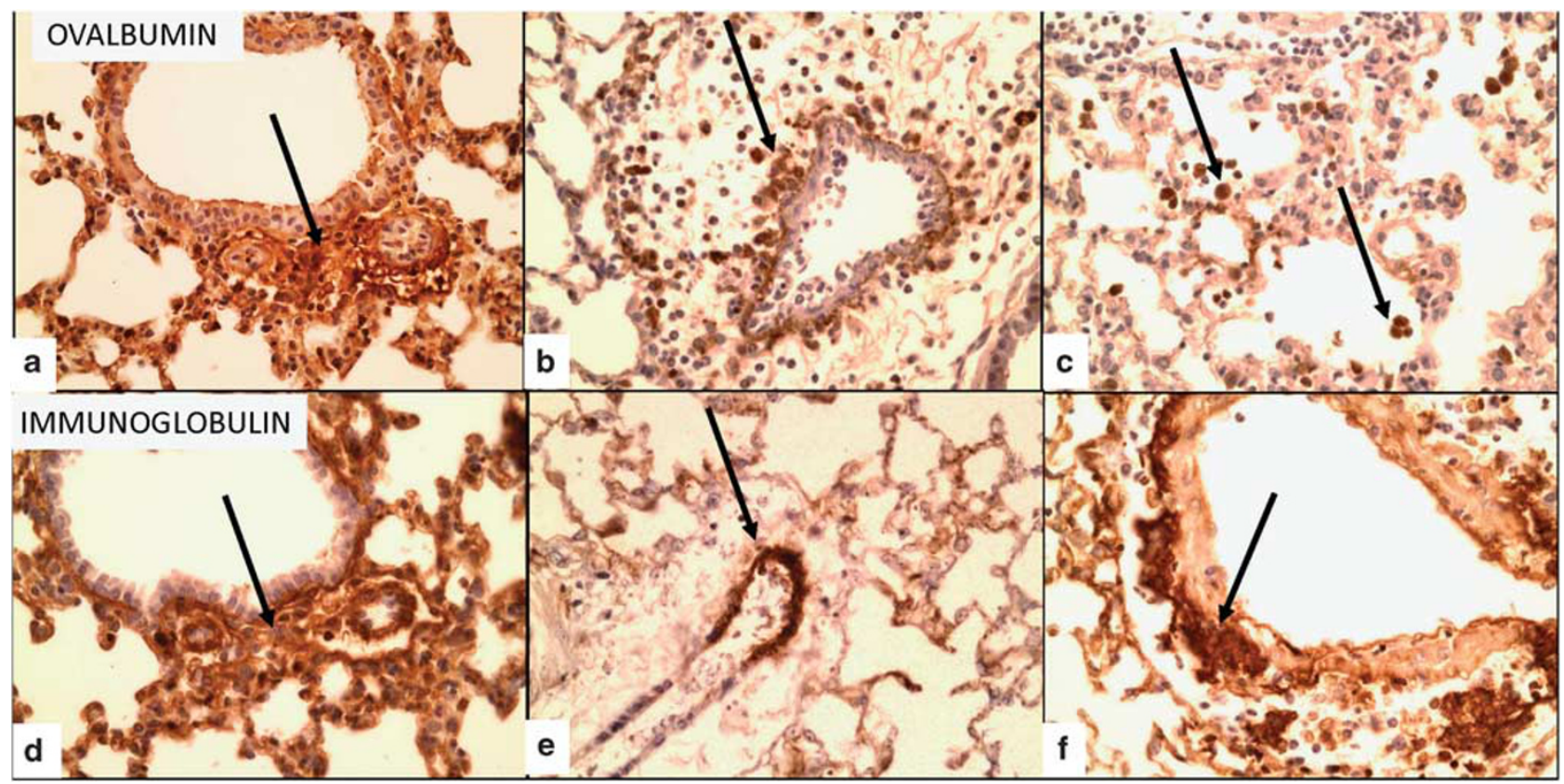

Figure 4 Immunoperoxidase labeling for OVA (a-c) and Ig (d-f) after pulmonary challenge. $200 \times$ or $400 \times$. a and $\mathbf{d}$ show faint perivascular labeling around small vessels (arrows) at 6 hours after a single challenge (See enlargements in Supplementary Figure 2). At 24 hours most of the OVA labeling is in macrophages both in zones of perivascular inflammation (b, arrow) and scattered in alveoli (c, arrows). This is also seen 6 hours after 3 challenges. At 24 hours Ig is seen as deposits in walls of vessels with inflammation (e), but not in macrophages. 6 hours after 3 challenges lg is seen as dense deposits around vessels (f). OVA is not seen $72 \mathrm{~h}$ after challenge.

Figure 5 iBALT formation after single (a-d), double (e-l), and triple challenge (m-q). (a-d) Single challenge, $72 \mathrm{~h}$. (e-h) Double challenge, $6 \mathrm{~h}$. (i-l) Double challenge, $72 \mathrm{~h}$. (m-q) Triple challenge, $24 \mathrm{~h}$. The first evidence of iBALT is a peribronchial cuff of B cells $72 \mathrm{~h}$ after a single challenge (a-d). This is also present $6 \mathrm{~h}$ after double challenge (e-h) and expands into larger zones of B cells (Pax5+) at $72 \mathrm{~h}$. (i-I) Peribronchial iBALT contains few, if any, eosinophils ( $\mathbf{n}$ and $\mathbf{~}$ ), although eosinophils are seen in adjacent Pax 5 - zones (compare $\mathbf{j}$ with $\mathbf{I}$ ). From 24 to $72 \mathrm{~h}$ after triple challenge, well-formed B-cell follicles appear around vessels next to bronchi $(\mathbf{m}-\mathbf{q})$. These consist of zones of Pax $5+$ B cells (white outline in $\mathbf{m}$, Pax 5 stain in $\mathbf{n}$ ) and Ig+, Pax5 - cells (black outline in $\mathbf{m}$, lg stain in $\mathbf{o})$, with less frequent $T$ cells $(C D 3, \mathbf{p})$ and macrophages $(F 4 / 80, \mathbf{q})$. The two top arrows in $\mathbf{m}$ point from Pax5 - zones to $\mathrm{lg}+$ zones in $\mathbf{0}$. The three lower arrows in $\mathbf{m}$ point from a Pax5+ zone to corresponding $\mathrm{lg}$ - zone in $\mathbf{0} ; \mathrm{CD} 3+\mathrm{zone}$ in $\mathbf{p}$ and $\mathrm{F} 4 / 80$ zone in q. Note mucous hyperplasia in $\mathbf{m}$. iBALT, induced bronchial associated lymphoid tissue; lg, immunoglobulin. 


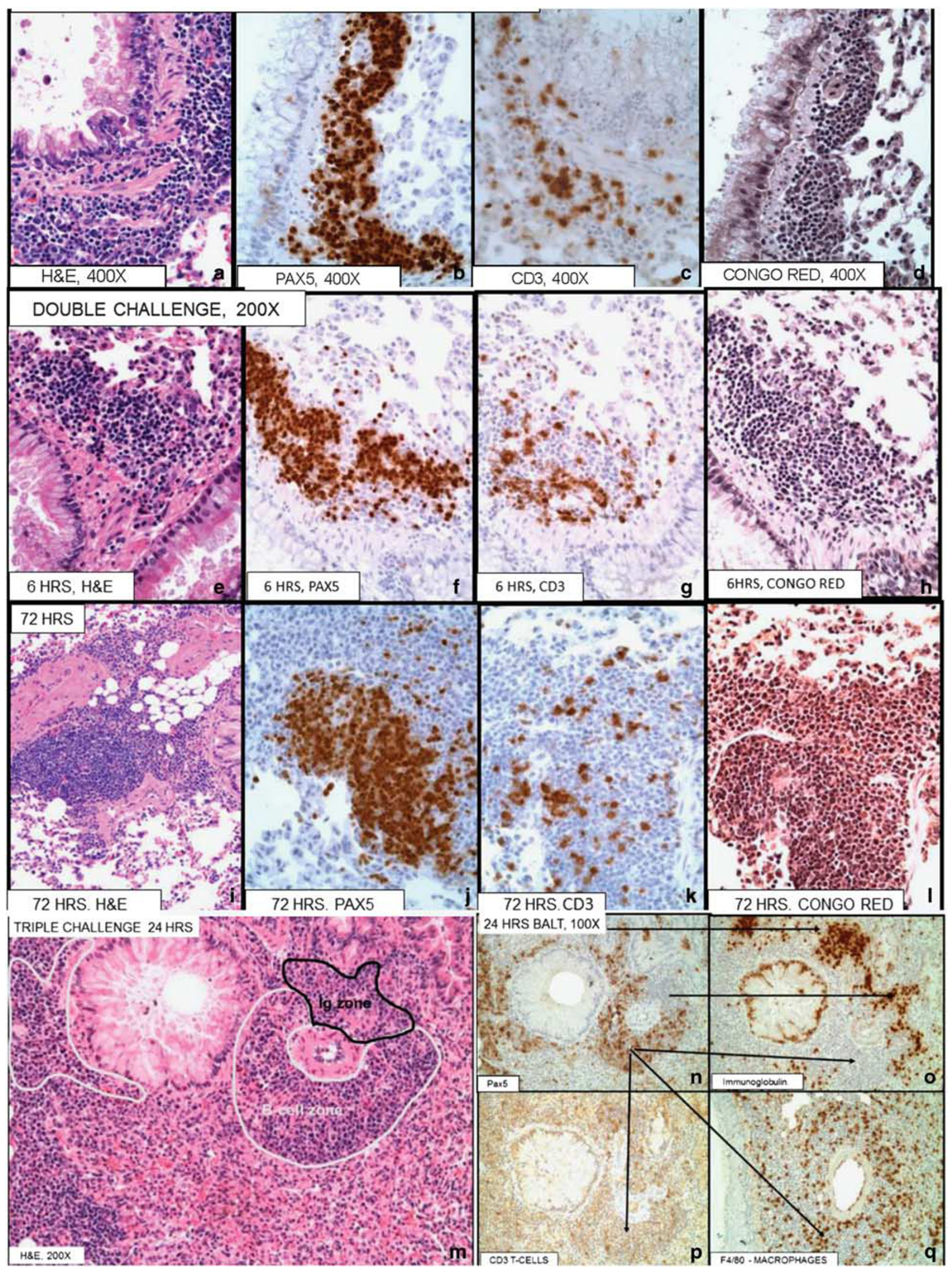



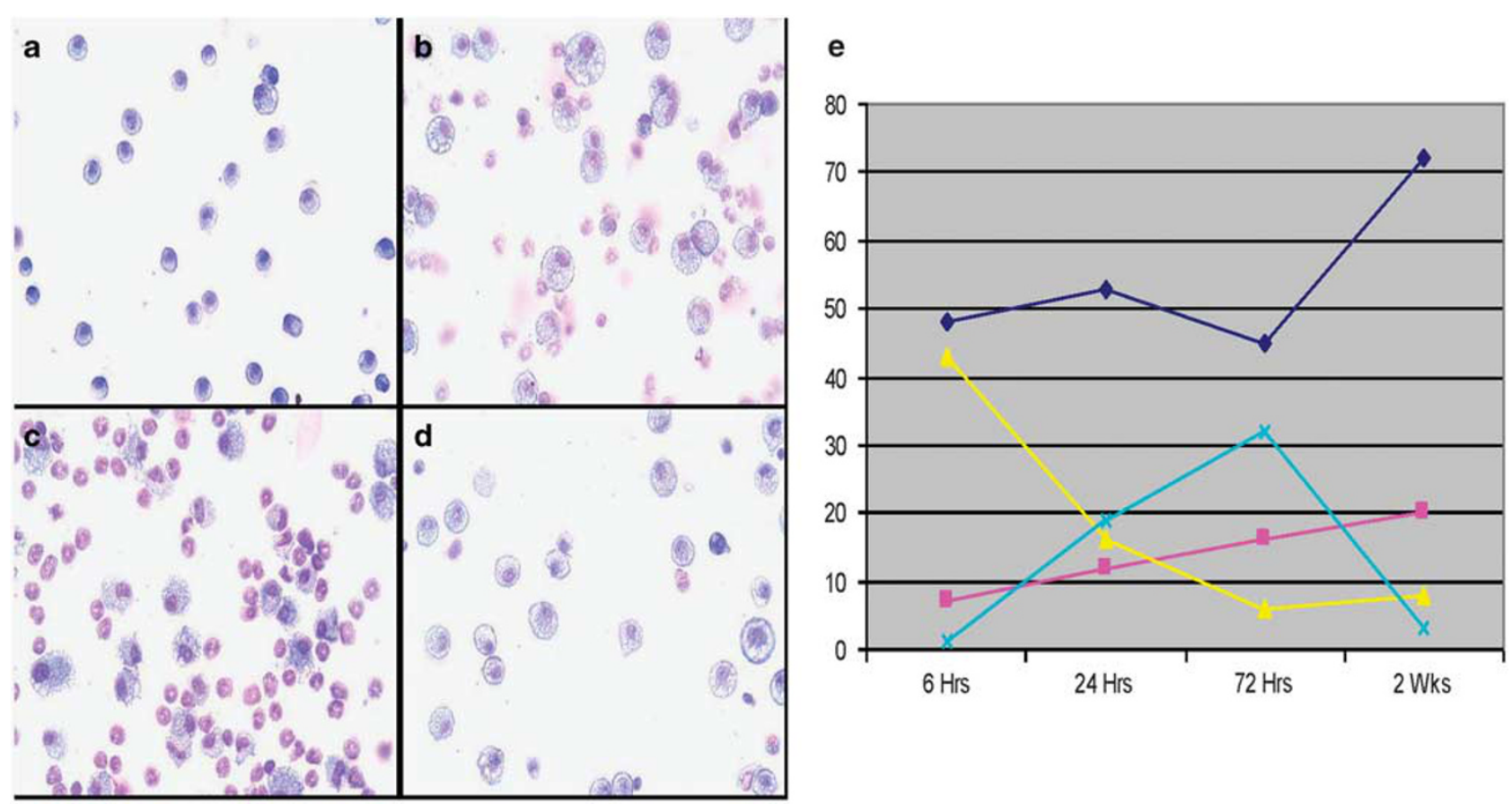

f

Ovalbumin-specific IgE levels in serum

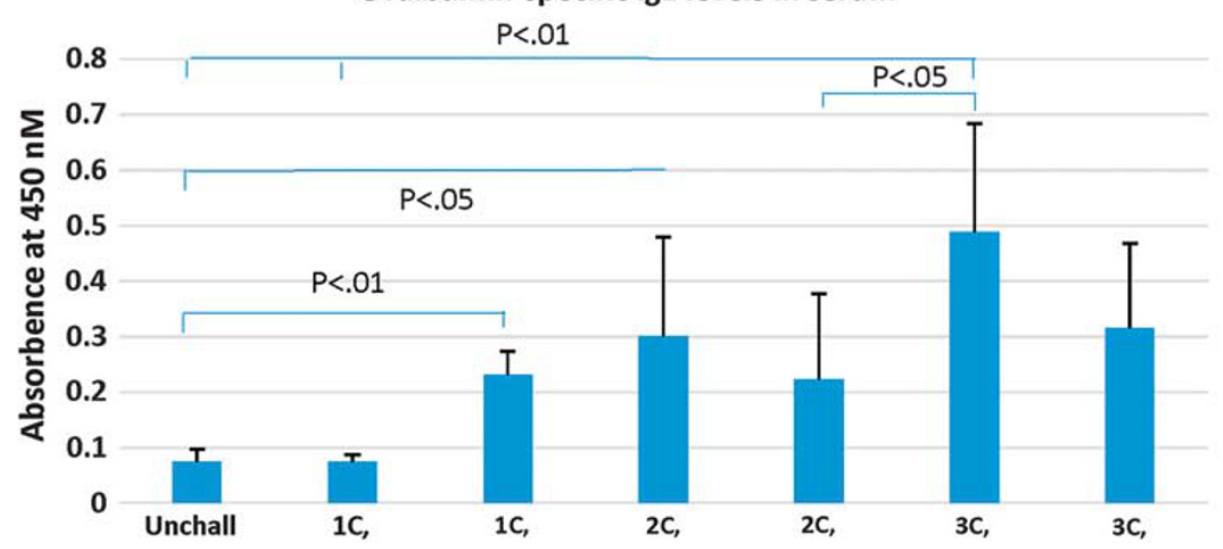

Figure 6 Cells in bronchial lavage fluid (BAL) and IgE antibody to OVA in sera. (a-d) Cells in BAL at 0, 24, 72 h, and 2 weeks. (e) Graph of percentage of cells: eosinophils_light blue; monocytes_dark blue; lymphocytes_red; neutrophils—yellow. The points in e represent the average of three mice. $\mathbf{f}$ shows development of IgE antibody to OVA at $48 \mathrm{~h}$ and 1 week after one, two, or three challenges. Significant increases first occur 1 week after the first challenge or $48 \mathrm{~h}$ after the second challenge, which is about the same time as $48 \mathrm{~h}$ after the second challenge ( 5 days after the first challenge). OVA, ovalbumin.

may contribute toxicity to the bronchial epithelium and to bronchoconstriction. ${ }^{47} \mathrm{~A}$ role for eosinophils is supported by the finding that the inflammation produced by the OVA challenge model is greatly reduced in mice depleted of eosinophils. ${ }^{48,49}$ However, the striking eosinophilic vasculitis has not been described previously because previous studies were done after three OVA challenges. We show that eosinophilic vasculitis is readily seen after one or two OVA challenges, but is essentially replaced by mononuclear vasculitis after three challenges (Figures 1 and 3). Although there is early fibrinoid necrosis, there appears to be little damage to bronchial epithelium or surrounding tissue and the lesions resolve quickly. Eosinophils contain at least five preformed enzymatic and non-enzymatic granular proteins that contribute to airway damage, inflammation, and tissue remodeling..$^{50}$ However, degranulation and peroxidase-mediated oxidation of airway proteins do not appear to play a significant role in OVA-induced inflammation in the mouse as mice deficient for eosinophil peroxidase display the same AHR and pathologies as wild-type mice. ${ }^{51}$

The accumulation of eosinophils in the lung instead of neutrophils that would be expected in an immune complex vasculitis is most likely mediated by CCL11 (chemokine C-C motif ligand 11, also called eotaxin), by Th2 cytokines (eg, IL-5) and by IL-23. CCL11 is increased in the OVA mouse model of asthma associated with AHR and pulmonary 


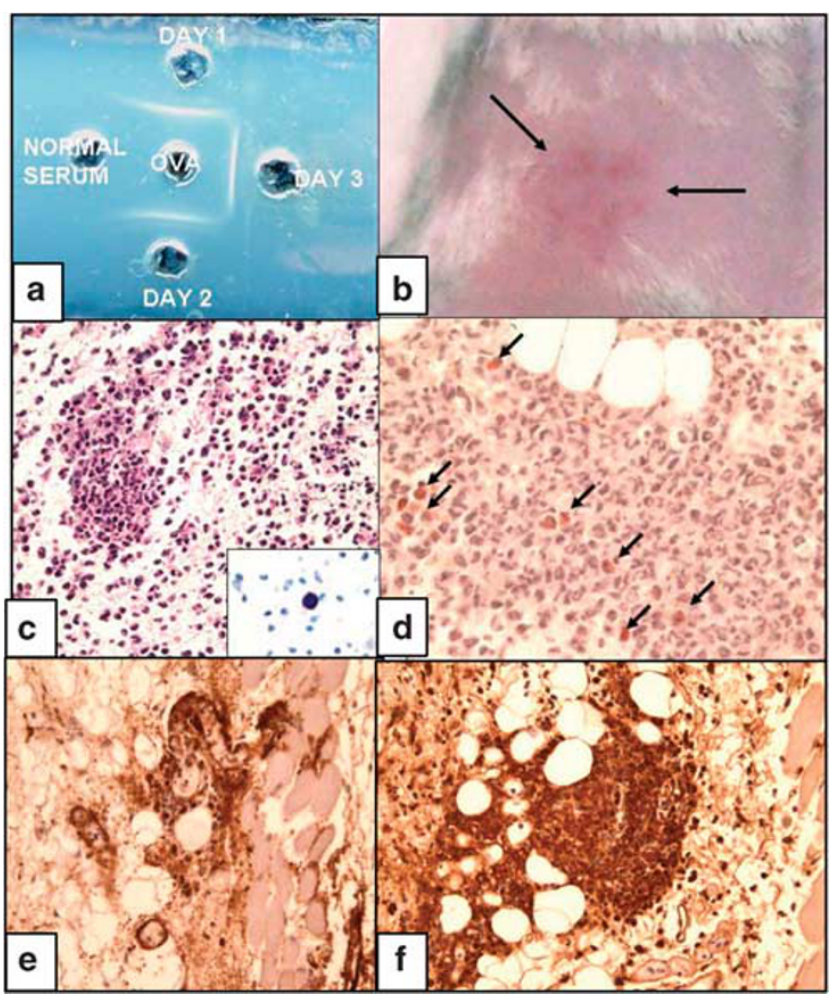

Figure 7 Precipitating antibody (gel diffusion) and cutaneous Arthus reaction. (a) Double-diffusion-in-agar showing precipitating antibody to OVA in sensitized mice. (b) Gross picture of skin showing area of inflammation after injection of OVA into skin of sensitized mouse (Arthus reaction). (c, e, $\mathbf{d}$, and $\mathbf{f}$ ) Congo Red staining of skin section of Arthus reaction showing predominance of neutrophils and few eosinophils (arrows in i) in dermis of skin $6 \mathrm{~h}$ after injection of OVA (Arthus reaction). Insert in c shows polychromatic staining of mast cells in the skin. (e) OVA and (f) lg immunoperoxidase staining. OVA, ovalbumin.

eosinophilia. ${ }^{52-54}$ Levels of CCL11 are consistently higher in asthmatic patients $v s$ controls. ${ }^{55} \mathrm{IL}-23$ is produced by activated macrophages and dendritic cells and stimulates IL-17 and IL-22 secretion from innate immune cells. ${ }^{56}$ Eosinophilic infiltrate is increased in transgenic mice overexpressing the IL-23 receptor, ${ }^{57,58}$ expression of eosinophilic peroxidase is greatly decreased in OVA challenged IL-23 knockout mice compared with WT mice, ${ }^{59}$ and inhibition of IL-23 release inhibits airway inflammation ${ }^{60}$ reduces AHR and the number of eosinophils in BAL after OVA challenge. ${ }^{61}$ We propose that activation of IL-23 may be enhanced by uptake by and activation of alveolar macrophages by OVA in sensitized mice. Activation of CCL11, IL-5, and IL-23 in the lung may explain why the acute inflammatory response to OVA challenge in the lung is eosinophilic, whereas that in the skin reaction is predominantly neutrophilic. ${ }^{23,24} \mathrm{IL}-23$ is most likely not activated in previously unchallenged skin and CCL11 is secreted by epithelial cells in the lung that are not present in the dermis of the skin.

GCHT and hyperplasia (GCHTH), a prominent feature in OVA-challenged mice, is first seen 3 days after the first challenge Figure 2). GCHTH is most likely stimulated by IL-17 (ref. 62) and other Th2 cytokines, such as IL-13 and IL-33 (ref. 63) as well as NF- $\kappa \mathrm{B} .{ }^{64} \mathrm{GCHT}$ and increased intrabronchial mucous most likely affects changes in air exchange but it is not clear how this affects airway hypersensitivity. In most reports of the mouse models, goblet cell hyperplasia is described. Our histologic analysis indicates an increase in size and mucous content of goblet cells (hypertrophy) and hyperplasia (increase in cell number), as well as smooth muscle hypertrophy.

Where are the mast cells? In human allergic reactions, binding of the allergen to IgE on mast cells with subsequent release of mediators is the classic mechanism of the acute asthmatic response and increased numbers of mast cells are present in the peribronchial inflammation seen in chronic asthma. Mast cells are not increased in OVA-challenged mice, ${ }^{65}$ and, are very rarely seen in normal mouse lung. ${ }^{66}$ However, mast cells have been described if sensitized mice are re-challenged repeatedly with OVA for 1 to 6 months. ${ }^{67}$ In the present study, mast cells were easily identified in the skin. However on careful scanning of sections selected to include the trachea and main stem bronchus of normal and inflamed lungs, 0 to 6 mast cells were seen only in the most proximal part of the main stem bronchus (Figures $3 \mathrm{~g}-\mathrm{j}$ ). This is consistent with the findings of Haile et al. ${ }^{68}$ that mast cells could be found in the connective tissue between the large vessels and the bronchi, but not in the smaller bronchi or alveolar tissue. They also did not see an increase in mast cells after challenge. Mast cells have been identified in the lungs and BAL of C57BL/6 mice by Fuchs et al. ${ }^{69}$ but the role of these in AHR is not definitive. They found that AHR was not different in wild-type and mast cell-deficient mice after OVA challenge, but reactivity in mast cell-deficient mice was increased after engraftment of bone marrow-derived mast cells. This interesting result suggests that putative resident mast cells in the lung, if present, do not contribute to AHR, but that transferred mast cells from the bone marrow do.

\section{iBALT Formation}

BALT is an adaptive immune response in the lung and is a site where local immune responses can occur rapidly after exposure to inhaled antigens. BALT is a constitutive mucosal lymphoid tissue in rats and rabbits, but is not present normally in humans or mice. However, BALT is inducible in humans and mice after inflammation in the lung, ${ }^{70,71}$ so-called iBALT. iBALT is seen in chronic lung infections in humans, ${ }^{72}$ as well as in mice with repeated virus infections of the lung. ${ }^{73}$ iBALT has also been described in humans with asthma. ${ }^{74}$ Mice lacking spleen, lymph nodes, and Peyer's patches develop iBALT in response to influenza challenge, clear influenza infection and, when BALT is present, survive higher doses of the virus than do normal mice. ${ }^{75}$ The presence of iBALT in response to one viral infection enhances the immune response to subsequent infection with unrelated viruses (heterologous immunity ${ }^{73}$ ). Thus, BALT may be 
considered a local site for immune memory that can respond quickly to a second pulmonary infection. IL-5 and IL-17, both elevated in OVA-sensitized mice, ${ }^{57,65,76-79}$ may act synergistically to stimulate iBALT formation. IL-5 increases B-cell proliferation. ${ }^{80}$ IL-17 increases expression of the chemokines CXCL12 and CXCL13 (ref. 81), which are critical for follicle formation $^{82}$ with or without the participation of dendritic cells. ${ }^{83}$ Thus, the late histologic changes in the OVA mouse lung inflammation model appear to be mediated by Th2 and Th17 cytokines and are rapidly reversed when these cytokines are no longer secreted.

\section{Comparison to Human Pulmonary Vasculitis}

It is not clear how this experimental induction of chronic vascular and peribronchial inflammation in the lung in mice compares to naturally occurring pulmonary vasculitis in humans. ${ }^{84,85}$ The lesions produced involve what would be considered medium-sized vessels in humans. This makes the small-vessel vasculitides associated with anti-neutrophil cytoplasmic antibody and the large vessels lesions, such as Giant cell arteritis and Takayasu's arteritis, unlikely candidates. Churg-Strauss syndrome is a likely candidate. ${ }^{86}$ Also known as eosinophilic granulomatosis with polyangitis or allergic granulomatosis, this syndrome features high numbers of eosinophils and eosinophilic vasculitis in the lung associated with asthma and/or allergic rhinitis. ${ }^{87}$ The lesions of adult respiratory distress syndrome involve small vessels and result in damage to the alveolar-capillary membrane, ${ }^{88}$ which is not seen in this model. The most likely associations for the acute lesions would be with primary immune complexmediated vasculitis, such as Goodpasture's syndrome involving the lung, polyarteritis nodosa, or serum sickness. However, there may be no naturally occurring lesions in the lung that correspond to those produced by the massive and multiple doses of soluble antigen to sensitized mice.

\section{Final Comments}

Of what use is the study of the physiologic changes or pharmacologic alterations of the mouse model of asthma for understanding human asthma? Clearly the sensitization and bronchial challenge of mice with OVA produces histologic changes in the bronchi consistent with human asthma. Thus, it could be argued that, even though the basic pathologic mechanism (immune complex vasculitis) is different from that of human asthma (atopic or anaphylactic), identifying physiologic mechanisms or efficacious treatment might be possible using this model. The role of an atopic mechanism in producing the bronchial lesions is unclear. Although IgE antibody becomes elevated after the first challenge, it is not elevated in sensitized, unchallenged mice, and mast cells are only seen in the most proximal main stem bronchi and not in the remaining main stem bronchi or more distal bronchi, where the asthma-like hypertrophy and hyperplasia of mucosa cells and smooth muscle hypertrophy are seen.
On the other hand, intervention directed against the underlying pathogenic mechanism of human asthma would not be possible in the mouse model because the reaction responsible for the lesions of the mouse model of asthma is not the same as for human asthma. For example, one of the possible mechanisms thought to mediate desensitization of allergic reactions by immunizing with the allergen is an attempt to shift the immune response from IgE antibody to IgG antibody. In this approach, the IgG antibody prevents the allergen from reacting with IgE on mast cells and thus inhibits the atopic reaction. However, in the mouse model it appears that IgG antibody actually initiates the pathologic response to OVA challenge; precipitating antibody is present in sensitized, unchallenged mice at a time when IgE antibody is not yet elevated.

Supplementary Information accompanies the paper on the Laboratory Investigation website (http://www.laboratoryinvestigation.org)

\section{ACKNOWLEDGMENTS}

We thank Helen Johnson at the Wadsworth Core Laboratory for help with cutting the tissue sections; Nancy Andersen for assistance with the Luminex assay; and Kathleen Curran for performing differential counts on peripheral blood smears.

\section{DISCLOSURE/CONFLICT OF INTEREST}

The authors declare that they have no conflicts of interest.

1. Nakajima H, Iwamoto I, Tomoe S et al. CD4+ T-lymphocytes and interleukin-5 mediate antigen-induced eosinophil infiltration into the mouse trachea. Am Rev Respir Dis 1992;146:374-377.

2. Cohn L. Food for thought: can immunological tolerance be induced to treat asthma? Am J Respir Cell Mol Biol 2001;24:509-512.

3. Zosky GR, Sly PD. Animal models of asthma. Clin Exp Allergy 2007;37: 973-988.

4. Nials AT, Uddin S. Mouse models of allergic asthma: acute and chronic allergen challenge. Dis Model Mech 2008;1:213-220.

5. Kumar RK, Foster PS. Are mouse models of asthma appropriate for investigating the pathogenesis of airway hyper-responsiveness? Front Physiol 2012;3:312.

6. Mullane $\mathrm{K}$, Williams $\mathrm{M}$. Animal models of asthma: reprise or reboot? Biochem Pharmacol 2014;87:131-139.

7. Kumar RK, Herbert C, Foster PS. The 'classical' ovalbumin challenge model of asthma in mice. Curr Drug Targets 2008;9:485-494.

8. Takeda K, Hamelmann E, Joetham A et al. Development of eosinophilic airway inflammation and airway hyperresponsiveness in mast celldeficient mice. J Exp Med 1997;186:449-454.

9. Yu M, Tsai M, Tam SY et al. Mast cells can promote the development of multiple features of chronic asthma in mice. J Clin Invest 2006;116: 1633-1641.

10. Mizutani N, Nabe T, Yoshino S. IL-17A promotes the exacerbation of IL-33-induced airway hyperresponsiveness by enhancing neutrophilic inflammation via CXCR2 signaling in mice. J Immunol 2014;192: 1372-1384.

11. Chvatchko $\mathrm{Y}$, Kosco-Vilbois $\mathrm{MH}$, Herren $\mathrm{S}$ et al. Germinal center formation and local immunoglobulin $\mathrm{E}$ (IgE) production in the lung after an airway antigenic challenge. J Exp Med 1996;184: 2353-2360.

12. Nabe $T$, Ikedo A, Hosokawa $F$ et al. Regulatory role of antigen-induced interleukin-10, produced by CD4(+) T cells, in airway neutrophilia in a murine model for asthma. Eur J Pharmacol 2012;677:154-162.

13. Brusselle GG, Kips JC, Tavernier JH et al. Attenuation of allergic airway inflammation in IL-4 deficient mice. Clin Exp Allergy 1994;24: 73-80. 
14. Ma W, Bryce PJ, Humbles AA et al. CCR3 is essential for skin eosinophilia and airway hyperresponsiveness in a murine model of allergic skin inflammation. J Clin Invest 2002;109:621-628.

15. Hessel EM, Van Oosterhout AJM, Garsen J et al. Immediate asthmatic reactions and changes in airway responsiveness after single vs chronic ovalbumin inhalation in sensitized mice. Eur J Allergy Clin Immunol 1993:48:101.

16. Kashiwakura JC, Ando T, Matsumoto $\mathrm{K}$ et al. Histamine-releasing factor has a proinflammatory role in mouse models of asthma and allergy. J Clin Invest 2012;122:218-228.

17. Shaw OM, Harper JL. An efficient single prime protocol for the induction of antigen-induced airways inflammation. J Immunol Methods 2013;395:79-82.

18. Albert EJ, Duplisea J, Dawicki W et al. Tissue eosinophilia in a mouse model of colitis is highly dependent on TLR2 and independent of mast cells. Am J Pathol 2011;178:150-160.

19. Sell S, Guest I, McKinstry KK et al. Immunopathology of influenza: Pulmonary viral exanthema, BALT and immune sensitive carcinoma in experimental mouse models. Viral Immunology 2014;27:1-13.

20. Kerstens HM, Poddighe PJ, Hanselaar AG. A novel in situ hybridization signal amplification method based on the deposition of biotinylated tyramine. J Histochem Cytochem 1995;43:347-352.

21. Hornbek P. Double-immunodiffusion assay for detecting specific antibodies. Curr Prot Immunol 2001; Unit 2.3:2.3.1-2.3.4.

22. Saloga J, Renz H, Lack G et al. Development and transfer of immediate cutaneous hypersensitivity in mice exposed to aerosolized antigen. J Clin Invest 1993:91:133-140.

23. Sell S. Immunology, Immunopathology and Immunity. ASM Press: Washington, DCWashington, DC, 2001.

24. Arthus M. Injections repetees de serum de cheval chez le lapin. C R Soc Biol (Paris) 1903:55:817.

25. Schlecht J, Schwenker G. Über die Beziehunger der Eosinophilie zur Anaphylaxie. Dtsch Arch Klin Med 1912;108:405-428.

26. Opie EL. The fate of antigen (protein) in an animal immunized against it. J Exp Med 1924;39:659-675.

27. Fried BM. Allergic lobar pneumonia: experimental study. J Exp Med 1933:57:111-119.

28. Cannon PR, Walsh TE, Marshall CE. Acute local anaphylactic inflammation of the lungs. Am J Pathol 1941;17:777-784.

29. McKinnon GE, Andrews Jr EC, Heptinstall RH et al. An immunohistochemical study of the occurrence of intravascular antigenantibody precipitation and its role in anaphylaxis in the rabbit. Bull Johns Hopkins Hosp 1957;101:258-280.

30. Eskensay A. Immunomorphology of experimental Arthus phenomenon of the lung. Rev Immunol (Paris) 1971;35:85-101.

31. Richerson HB, Cheng FH, Bauserman SC. Acute experimental hypersensitivity pneumonitis in rabbits. Am Rev Respir Dis 1971;104: 568-575.

32. Eastham WN, Muller HK. Changes in guinea-pig lungs following the inhalation of powdered egg albumen. Pathology 1972;4:235-241.

33. Kallos $P$, Kallos $L$. Experimental asthma in guinea pigs revisited. Int Arch Allergy Appl Immunol 1984;73:77-85.

34. Kung $\Pi$, Jones $\mathrm{H}$, Adams 3rd GK et al. Characterization of a murine model of allergic pulmonary inflammation. Int Arch Allergy Immunol 1994;105:83-90.

35. Sanjar S, Aoki S, Kristersson A et al. Antigen challenge induces pulmonary airway eosinophil accumulation and airway hyperreactivity in sensitized guinea-pigs: the effect of anti-asthma drugs. $\mathrm{Br} J$ Pharmacol 1990;99:679-686.

36. Johnson KJ, Ward PA. Acute immunologic pulmonary alveolitis. J Clin Invest 1974;54:349-357.

37. McCormick JR, Harkin MM, Johnson KJ et al. Suppression by superoxide dismutase of immune-complex-induced pulmonary alveolitis and dermal inflammation. Am J Pathol 1981;102:55-61.

38. Warren JS, Yabroff KR, Remick DG et al. Tumor necrosis factor participates in the pathogenesis of acute immune complex alveolitis in the rat. J Clin Invest 1989;84:1873-1882.

39. Mulligan MS, Varani J, Dame MK et al. Role of endothelial-leukocyte adhesion molecule 1 (ELAM-1) in neutrophil-mediated lung injury in rats. J Clin Invest 1991;88:1396-1406.

40. Mulligan MS, Varani J, Warren JS et al. Roles of beta 2 integrins of rat neutrophils in complement- and oxygen radical-mediated acute inflammatory injury. J Immunol 1992;148:1847-1857.
41. Baumann U, Chouchakova N, Gewecke B et al. Distinct tissue site-specific requirements of mast cells and complement components C3/C5a receptor in lgG immune complex-induced injury of skin and lung. J Immunol 2001;167:1022-1027.

42. Shushakova $N$, Eden $G$, Dangers $M$ et al. The urokinase/urokinase receptor system mediates the IgG immune complex-induced inflammation in lung. J Immunol 2005;175:4060-4068.

43. Skokowa J, Ali SR, Felda O et al. Macrophages induce the inflammatory response in the pulmonary Arthus reaction through G alpha i2 activation that controls C5aR and Fc receptor cooperation. J Immunol 2005;174:3041-3050.

44. Wiege K, Ali SR, Gewecke B et al. Galphai2 is the essential Galphai protein in immune complex-induced lung disease. J Immunol 2013;190:324-333.

45. Wilson SJ, Harmer MJ, Lee RL et al. Recurring BALB/C mouse lung inflammatory responses to episodic allergen exposure. J Toxicol Environ Health A 2013;76:176-191.

46. Sutherland MA, Shome GP, Hulbert LE et al. Acute stress affects the physiology and behavior of allergic mice. Physiol Behav 2009;98: 281-287.

47. Wardlaw AJ, Brightling C, Green R et al. Eosinophils in asthma and other allergic diseases. Br Med Bull 2000;56:985-1003.

48. Lee JJ, Dimina D, Macias MP et al. Defining a link with asthma in mice congenitally deficient in eosinophils. Science 2004;305:1773-1776.

49. Humbles AA, Lloyd CM, McMillan SJ et al. A critical role for eosinophils in allergic airways remodeling. Science 2004;305:1776-1779.

50. Acharya KR, Ackerman SJ. Eosinophil granule proteins: form and function. J Biol Chem 2014;289:17406-17415.

51. Denzler KL, Borchers MT, Crosby JR et al. Extensive eosinophil degranulation and peroxidase-mediated oxidation of airway proteins do not occur in a mouse ovalbumin-challenge model of pulmonary inflammation. J Immunol 2001;167:1672-1682.

52. Scheerens J, van Gessel SB, Nijkamp FP et al. Eotaxin protein levels and airway pathology in a mouse model for allergic asthma. Eur $J$ Pharmacol 2002;453:111-117.

53. Eum SY, Maghni K, Hamid Q et al. Inhibition of allergic airways inflammation and airway hyperresponsiveness in mice by dexamethasone: role of eosinophils, IL-5, eotaxin, and IL-13. J Allergy Clin Immunol 2003;111:1049-1061.

54. Baek KJ, Cho JY, Rosenthal P et al. Hypoxia potentiates allergen induction of HIF-1alpha, chemokines, airway inflammation, TGF-beta1, and airway remodeling in a mouse model. Clin Immunol 2013;147: 27-37.

55. Wu D, Zhou J, Bi H et al. CCL11 as a potential diagnostic marker for asthma? J Asthma 2014;51:847-854.

56. McAleer JP, Kolls JK. Directing traffic: IL-17 and IL-22 coordinate pulmonary immune defense. Immunol Rev 2014;260:129-144.

57. Li Y, Hua S. Mechanisms of pathogenesis in allergic asthma: role of interleukin-23. Respirology 2014;19:663-669.

58. Peng J, Yang XO, Chang SH et al. IL-23 signaling enhances Th2 polarization and regulates allergic airway inflammation. Cell Res 2010;20:62-71.

59. Ciprandi G, Cuppari C, Salpietro C. Serum IL-23: a surrogate biomarker for asthma? Clin Exp Allergy 2012;42:1416-1417 author reply 1418.

60. Ishizuka T, Hisada T, Aoki $\mathrm{H}$ et al. Resolvin E1: a novel lipid mediator in the resolution of allergic airway inflammation. Exp Rev Clin Immunol 2008:4:669-672.

61. Masaki K, Suzuki $Y$, Kagawa $S$ et al. Dual role of interleukin-23 in epicutaneously-sensitized asthma in mice. Allergol Int 2014;63():13-22.

62. Xia W, Bai J, Wu X et al. Interleukin-17 A promotes MUC5AC expression and goblet cell hyperplasia in nasal polyps via the Act1-mediated pathway. PLoS One 2014;9:e98915.

63. Tanabe T, Shimokawaji $\mathrm{T}$, Kanoh $\mathrm{S}$ et al. IL-33 stimulates CXCL8/ IL-8 secretion in goblet cells but not normally differentiated airway cells. Clin Exp Allergy 2014;44:540-552.

64. Zhou E, Fu Y, Wei Z et al. Inhibition of allergic airway inflammation through the blockage of NF-kappaB activation by ellagic acid in an ovalbumininduced mouse asthma model. Food Funct 2014;5:2106-2112.

65. Durrant DM, Gaffen SL, Riesenfeld EP et al. Development of allergeninduced airway inflammation in the absence of T-bet regulation is dependent on IL-17. J Immunol 2009;183:5293-5300.

66. Gersch C, Dewald O, Zoerlein $M$ et al. Mast cells and macrophages in normal C57/BL/6 mice. Histochem Cell Biol 2002;118:41-49. 
67. Ikeda RK, Miller M, Nayar J et al. Accumulation of peribronchial mast cells in a mouse model of ovalbumin allergen induced chronic airway inflammation: modulation by immunostimulatory DNA sequences. J Immunol 2003;171:4860-4867.

68. Haile S, Lefort J, Joseph D et al. Mucous-cell metaplasia and inflammatory-cell recruitment are dissociated in allergic mice after antibody- and drug-dependent cell depletion in a murine model of asthma. Am J Respir Cell Mol Biol 1999;20:891-902.

69. Fuchs B, Sjoberg L, Moller Westerberg $C$ et al. Mast cell engraftment of the peripheral lung enhances airway hyperresponsiveness in a mouse asthma model. Am J Physiol Lung Cell Mol Physiol 2012;303:L1027-L1036.

70. Randall TD. Bronchus-associated lymphoid tissue (BALT) structure and function. Adv Immunol 2010;107:187-241.

71. Shilling RA, Williams JW, Perera J et al. Autoreactive T and B cells induce the development of bronchus-associated lymphoid tissue in the lung. Am J Respir Cell Mol Biol 2013;48:406-414.

72. Tschernig T, Pabst R. Bronchus-associated lymphoid tissue (BALT) is not present in the normal adult lung but in different diseases. Pathobiology 2000;68:1-8.

73. Chen $H D$, Fraire $A E$, Joris I et al. Specific history of heterologous virus infections determines anti-viral immunity and immunopathology in the lung. Am J Pathol 2003;163:1341-1355.

74. Elliot JG, Jensen CM, Mutavdzic S et al. Aggregations of lymphoid cells in the airways of nonsmokers, smokers, and subjects with asthma. Am Jespir Crit Care Med 2004;169:712-718.

75. Moyron-Quiroz JE, Rangel-Moreno J, Kusser $\mathrm{K}$ et al. Role of inducible bronchus associated lymphoid tissue (BBALT) in respiratory immunity. Nat Med 2004;10:927-934.

76. McKinley L, Alcorn JF, Peterson A et al. TH17 cells mediate steroidresistant airway inflammation and airway hyperresponsiveness in mice. J Immunol 2008;181:4089-4097.
77. Ishioka $\mathrm{T}$, Yamada $\mathrm{Y}$, Kimura $\mathrm{H}$ et al. Elevated macrophage inflammatory protein 1alpha and interleukin-17 production in an experimental asthma model infected with respiratory syncytial virus. Int Arch Allergy Immunol 2013;161():129-137.

78. Kim MS, Cho KA, Cho YJ et al. Effects of interleukin-9 blockade on chronic airway inflammation in murine asthma models. Allergy Asthma Immunol Res 2013;5:197-206.

79. Kang JY, Lee SY, Rhee CK et al. Effect of aging on airway remodeling and muscarinic receptors in a murine acute asthma model. Clin Interv Aging 2013;8:1393-1403.

80. Kouro T, Takatsu K. IL-5- and eosinophil-mediated inflammation: from discovery to therapy. Int Immunol 2009;21:1303-1309.

81. Korn T, Bettelli E, Oukka M et al. IL-17 and Th17 cells. Annu Rev Immunol 2009;27:485-517.

82. Rangel-Moreno J, Carragher DM, de la Luz Garcia-Hernandez M et al. The development of inducible bronchus-associated lymphoid tissue depends on IL-17. Nat Immunol 2011;12:639-646.

83. Fleige $\mathrm{H}$, Ravens $\mathrm{S}$, Moschovakis $\mathrm{GL}$ et al. IL-17-induced CXCL12 recruits $B$ cells and induces follicle formation in BALT in the absence of differentiated FDCs. J Exp Med 2014;211:643-651.

84. Jennette JC, Falk RJ. Small-vessel vasculitis. N Engl J Med 1997;337: 1512-1523.

85. Brown KK. Pulmonary vasculitis. Proc Am Thorac Soc 2006;3:48-57.

86. Churg J, Strauss L. Allergic granulomatosis, allergic angiitis, and periarteritis nodosa. Am J Pathol 1951;27:277-301.

87. Hellmich B, Ehlers S, Csernok $\mathrm{E}$ et al. Update on the pathogenesis of Churg-Strauss syndrome. Clin Exp Rheumatol 2003;21: S69-S77.

88. Thommasen HV. The role of the polymorphonuclear leukocyte in the pathogenesis of the adult respiratory distress syndrome. Clin Invest Med 1985;8:185-194. 